\title{
$\mathrm{CB}_{1}$ Receptor Signaling in the Brain: Extracting Specificity from Ubiquity
}

\author{
Arnau Busquets-Garcia ${ }^{\star, 1,2,4}$, Jaideep Bains ${ }^{\star, 3,4}$ and Giovanni Marsicano, 1,2,4 \\ ${ }^{1}$ INSERM U1215, NeuroCentre Magendie, Team 'Endocannabinoids and Neuroadaptation', Bordeaux, France; '2Université de \\ Bordeaux, Bordeaux, France; ' ${ }^{3}$ Department of Physiology and Pharmacology, Hotchkiss Brain Institute, University of Calgary, \\ Calgary, AB, Canada
}

\begin{abstract}
Endocannabinoids (eCBs) are amongst the most ubiquitous signaling molecules in the nervous system. Over the past few decades, observations based on a large volume of work, first examining the pharmacological effects of exogenous cannabinoids, and then the physiological functions of eCBs, have directly challenged long-held and dogmatic views about communication, plasticity and behavior in the central nervous system (CNS). The eCBs and their cognate cannabinoid receptors exhibit a number of unique properties that distinguish them from the widely studied classical amino-acid transmitters, neuropeptides, and catecholamines. Although we now have a loose set of mechanistic rules based on experimental findings, new studies continue to reveal that our understanding of the eCB system (ECS) is continuously evolving and challenging long-held conventions. Here we will briefly summarize findings on the current canonical view of the 'ECS' and will address novel aspects that reveal how a nearly ubiquitous system can determine highly specific functions in the brain. In particular, we will focus on findings that push for an expansion of our ideas around long-held beliefs about eCB signaling that, while clearly true, may be contributing to an oversimplified perspective on how cannabinoid signaling at the microscopic level impacts behavior at the macroscopic level.

Neuropsychopharmacology Reviews (2018) 43, 4-20; doi:I0.1038/npp.2017.206; published online 18 October 2017
\end{abstract}

\section{SIGNALING OF $\mathrm{CB}_{1}$ RECEPTORS IN THE BRAIN: INTRINSIC OR EMERGING FEATURES?}

Despite the ever-growing complexity of the data and the constant addition of new players, most of what is known in the brain concerning the functions of the endocannabinoid $(\mathrm{eCB})$ system (ECS) refers to type 1 cannabinoid $\left(\mathrm{CB}_{1}\right)$ receptors. Therefore, in sake of brevity, this short review will mainly focus on the properties of $\mathrm{CB}_{1}$ receptors. The reader is referred to recent papers and reviews for enlarged visions of the ECS in the

\footnotetext{
${ }^{*}$ Correspondence: Dr A Busquets-Garcia, INSERM U1215, NeuroCentre Magendie and Université de Bordeaux, Team 'Endocannabinoids and Neuroadaptation', 146, rue Leo Saignat, 33077 Bordeaux, France; Tel: +33 55757 3756; Fax: +33 557573751 E-mail: arnau.busquets-garcia@ inserm.fr, Dr J Bains, Department of Physiology and Pharmacology, Hotchkiss Brain Institute, University of Calgary, 3330 Hospital Drive NW, Calgary, AB, Canada T2N4N1; Tel: +14032207585; Fax: +14032832700. E-mail: jsbains@ucalgary.ca, Dr G Marsicano, INSERM U1215, NeuroCentre Magendie and Université de Bordeaux, Team 'Endocannabinoids and Neuroadaptation', 146, rue Leo Saignat, 33077 Bordeaux, France; Tel: +33 55757 3756; Fax: +33 55757 3751. E-mail giovanni.marsicano@inserm.fr

${ }^{4}$ These authors contributed equally to this work.

Received 21 April 2017; revised 22 July 2017; accepted 14 August 2017; accepted article preview online 1 September 2017
}

central nervous system (CNS), such as, for instance, the potential importance of type 2 cannabinoid $\left(\mathrm{CB}_{2}\right)$ receptors in certain central functions (Fernandez-Ruiz et al, 2008; Li and Kim, 2016; Navarro et al, 2016; Onaivi et al, 2012; OrtegaAlvaro et al, 2011) or of non-cannabinoid receptor targets of eCBs (Di Marzo et al, 2002; Sigel et al, 2011).

$\mathrm{CB}_{1}$ receptor is a seven transmembrane $\mathrm{G}$ protein-coupled receptor (GPCR), and its properties encompass a great deal of molecular, cellular and functional complexity. It is well known that similarly to many other GPCRs (Gentles and Karlin, 1999), the coding region of the cannabinoid receptor type 1 (cnrl) gene is intronless. This means that the expression of the cnrl gene will have one major RNA processing event to skip, accelerating its protein expression. This advantage may have implications related to the biological functions of the $\mathrm{CB}_{1}$ receptors (Onaivi et al, 1999). Nevertheless, the presence of splice isoforms both in humans and mice (Ruehle et al, 2017), coming from 5'-UTR introns of the gene, and possible post-translational modifications demonstrates that $\mathrm{CB}_{1}$ receptors can come in different flavors already at transcriptional and translational level, with potential signaling differences (Bagher $e t a l, 2013$; Oddi $e t a l$, 2017; Straiker et al, 2012). Besides these gene expression variables, however, a number of recent observations indicate that $\mathrm{CB}_{1}$ receptor signaling is pleiotropic and depends on 


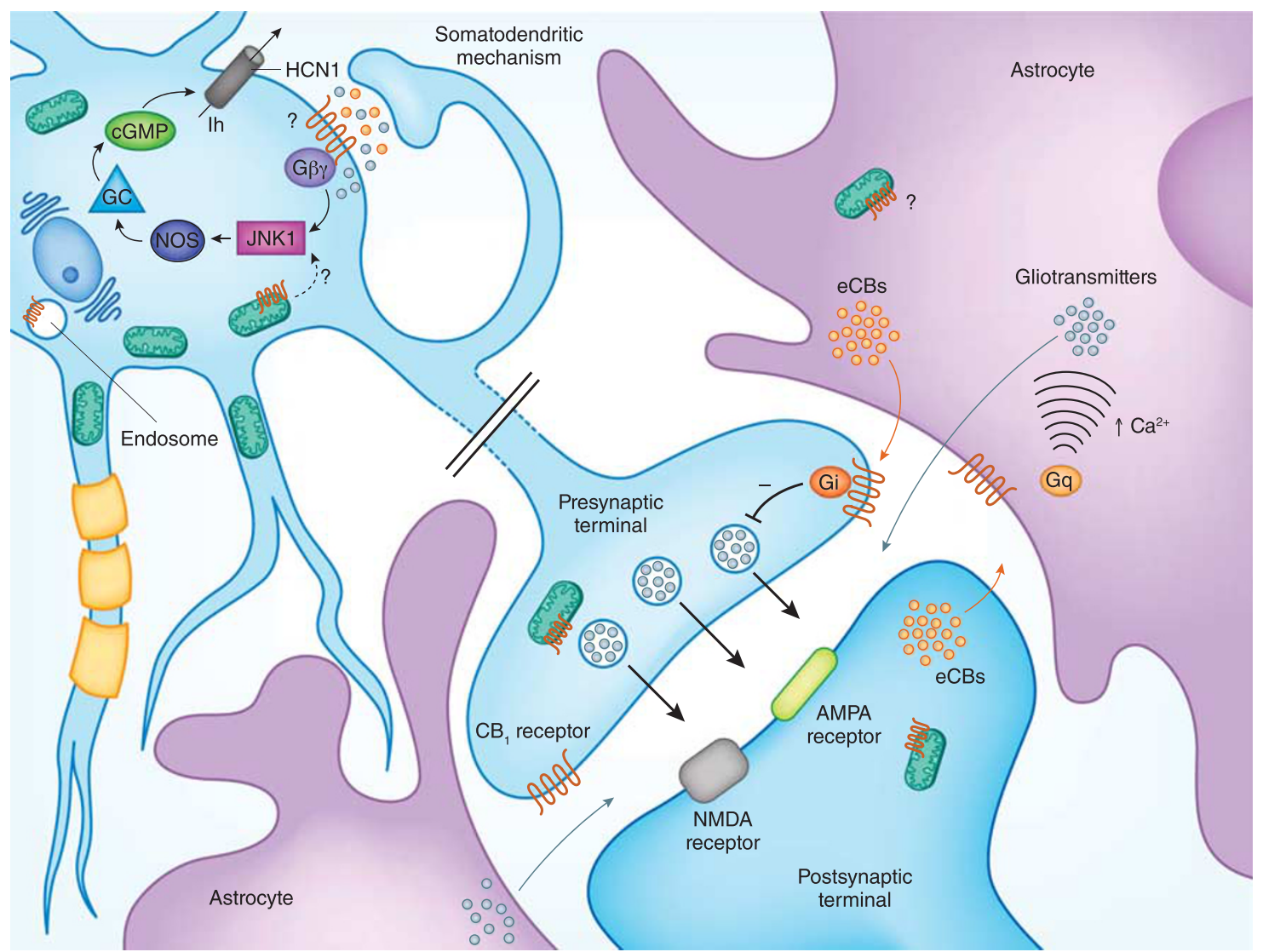

Figure 1. Schematic view of potential localizations of $\mathrm{CB}_{1}$ receptors at the synapse. $\mathrm{CB}_{1}$ receptors are present at both presynaptic terminals and postsynaptic compartments of neurons and on astrocytes, exerting different impacts at the tripartite synapse. Whereas the presynaptic plasma membrane localization is long recognized, new evidence points to the presence of $\mathrm{CB}_{1}$ at mitochondrial membranes of both presynaptic and somatodendritic compartments of neurons, although their specific functions are still to be fully determined. The presence of $\mathrm{CB}_{1}$ at postsynaptic plasma membranes is possible, but no direct anatomical evidence for this exists so far. Endosomal $\mathrm{CB}_{1}$ expression has been also proposed by different studies. $\mathrm{CB}_{1}$ (and possibly $\mathrm{mtCB}_{1}$ ) receptors are present in astrocytes, where they control astroglial synaptic functions. For additional information see the main text.

several additional factors, such as its cellular and subcellular localization. In this section, we will discuss the heterogeneity of $\mathrm{CB}_{1}$ receptor signaling in the CNS. Specifically, we will address the differential signaling properties of $\mathrm{CB}_{1}$ receptors present in different brain cells and in different subcellular locations (Figure 1). In addition, we will underline how the ECS is endowed with specific regulatory mechanisms at cellular level.

\section{Coupling Between $\mathrm{CB}_{1}$ Receptors and $\mathrm{G}$ Proteins: Cell-Type Specificity}

The brain is the most heterogeneous organ of the body and arguably the most complex biological system in nature. This is an acquired concept that is reported in all textbooks dealing with the issue. Nevertheless, for obvious limits of deep knowledge and difficulties in conceptualizing a 'machine' that is continuously changing, textbooks often tend to provide 'frozen' pictures of the cellular processes of brain cells and of their interactions. In other words, neuroscientists are aware that the brain is a complex and ever changing system, but its molecular elements are seen as 'static' bricks whose intrinsic properties combined together give rise to the complex phenomena allowing the brain to do all the beautiful things it does. In this perspective, receptors, channels, neurotransmitters, and all the molecular 'bricks' of the brain would have few or many intrinsic functions, and the complexity would rise from the combination of such individual modules. Thus, for instance, receptors were generally considered to induce the same effects in the cells expressing them. $\mathrm{CB}_{1}$ receptors have been classically described to activate or inhibit a series of intracellular cascades and we tend to assign these effects to the receptor at the different locations where it is present. Recent advances, however, suggest that $\mathrm{CB}_{1}$ receptors seem to have only a few 'intrinsic' signaling properties, but their effects largely 'emerge' from specific temporal and spatial constraints. For instance, $\mathrm{CB}_{1}$ receptors can regulate different $\mathrm{G}$ proteins in brain cells, and this ability seems to largely depend on the 'context' (cell type, subcellular location, cellular functional state, and so on) where they are activated. Far from providing a fully comprehensive account of $\mathrm{CB}_{1}$ receptor signaling in the brain, the next section will provide some key examples to argue for the 'emerging' properties of $\mathrm{CB}_{1}$ receptors. 


\section{Different Cells, Different G Protein Machinery?}

$\mathrm{CB}_{1}$ receptors likely have the highest expression of any GPCR in the brain, with amounts of protein comparable to NMDA and $\mathrm{GABA}_{\mathrm{A}}$ receptors (Freund et al, 2003; Herkenham et al, 1990; Howlett et al, 2002; Piomelli, 2003). They are present in many different cell types, but their levels of expression are astonishingly variable amongst different locations. Thus, cortical GABAergic interneurons contain prodigious levels of $\mathrm{CB}_{1}$ receptor protein, whereas cortical glutamatergic neurons have much lower levels of these receptors. By contrast, expression levels are relatively low in hypothalamic regions (Wittmann et al, 2007), but functional studies indicate that both glutamate and GABA neurons express $\mathrm{CB}_{1}$ receptors at similar levels (Wamsteeker and Bains, 2010a). Astroglial cells and, possibly, other glial cells likely contain even lower amounts of the protein (Han et al, 2012; Mato et al, 2009; Navarrete and Araque, 2008). Other neuronal types, such as noradrenergic, cholinergic, serotonergic, possibly dopaminergic, and others, also contain low-to-moderate levels of $\mathrm{CB}_{1}$ receptor protein (Marsicano and Kuner, 2008). If the signaling of $\mathrm{CB}_{1}$ receptors was an intrinsic property, one would expect that the levels of agonist-induced recruitment of $\mathrm{G}$ proteins are proportional to the levels of expression. However, this does not seem to be the case. Early studies showed that brain regions containing relatively low levels of $\mathrm{CB}_{1}$ receptor, such as the hypothalamus, display higher levels of cannabinoid-dependent signaling than regions expressing much higher levels of the protein (Breivogel et al, 1997). More recent studies using conditional mutant mice lacking $\mathrm{CB}_{1}$ receptor expression in specific neuronal subpopulations indicate that within the same brain region (hippocampus), the $\mathrm{G}$ protein activation by $\mathrm{CB}_{1}$ receptors expressed in glutamatergic neurons is much stronger than the one induced in GABAergic interneurons (Steindel et al, 2013). Thus, deletion of the receptor from cortical glutamatergic neurons (Glu- $\mathrm{CB}_{1}-\mathrm{KO}$ mice) only slightly reduces agonist binding and protein expression $(<10-20 \%)$, but it decreases $G$ protein activation (as measured by GTPgamma-binding assays on tissue extracts) by $\sim 50 \%$. Conversely and surprisingly, deletion of the $C B_{1}$ gene in forebrain GABAergic neurons (GABA-CB $B_{1}-\mathrm{KO}$ mice) strongly reduces the amount of protein in the hippocampus (more than 90\%), but it induces a lower decrease of $\mathrm{G}$ protein activation than in Glu- $C B_{1}-\mathrm{KO}$ mice (Steindel et al, 2013). This indicates a much higher efficacy of $\mathrm{G}$ protein-dependent signaling of $\mathrm{CB}_{1}$ receptors in hippocampal glutamatergic neurons than in neighboring GABAergic interneurons. The reasons of these cellular differences are not known at the moment. As also discussed below, the different abundance of $\mathrm{CB}_{1}$ receptor protein in hippocampal GABAergic $v s$ glutamatergic neurons can induce different stoichiometric relationships between the receptor and G proteins, thereby changing the efficiency of coupling. However, these data indicate that $G$ protein-coupling efficacy is clearly not an intrinsic property of $\mathrm{CB}_{1}$ receptors, but it is an emerging feature, depending on the cell type or subcellular compartment where they are expressed. Importantly, these processes can explain the huge cell-type-specific plethora of behavioral effects induced by cannabinoid drugs, as we will see below. Moreover, as described below, G protein-independent signaling (eg, arrestins) (Raehal and Bohn, 2014; Turu and Hunyady, 2010; Rozenfeld and Devi, 2008) can also be found and are important to consider when talking about $\mathrm{CB}_{1}$ receptor signaling.

The design logic for why certain cell types (eg, cortical GABAergic interneurons) express high levels of $\mathrm{CB}_{1}$ receptors and yet exhibit low-efficiency signaling through $\mathrm{G}$ proteins remains elusive. One hypothesis is that the pool of $\mathrm{CB}_{1}$ receptors in these cells might function as a sort of reservoir that is available to be rapidly used in certain conditions. Complementary to this idea, it is interesting to note that $\mathrm{CB}_{1}$ receptors were shown several years ago to be able to 'sequester' $\mathrm{G}_{\mathrm{i} / \mathrm{o}}$ proteins (Vasquez and Lewis, 1999) making them unavailable to other GPCRs expressed in the same cells. This could theoretically explain why large amounts of the receptor are present, but 'silent' in certain cell types. However, if these in vitro results apply also to ex vivo or in vivo conditions remains to be explored. The presence of $\mathrm{CB}_{1}$-interacting proteins could have a role in the cell-specific modulation of cannabinoid signaling. For instance, $\mathrm{CB}_{1}$ receptors have been proposed to form homodimers (Wager-Miller et al, 2002) and heterodimers with other GPCRs (Hudson et al, 2010), including, for instance, dopamine D2 (Kearn et al, 2005; Khan and Lee, 2014), opioid (Hojo et al, 2008), orexin (Perrey et al, 2014), serotonergic (Vinals et al, 2015), or $\mathrm{CB}_{2}$ receptors (Callen et al, 2012). These potential physical interactions are obviously cell-type-specific, and can modify the signaling of different pools of $\mathrm{CB}_{1}$ receptors. In this sense, two recent studies showed how (i) heteromers between $\mathrm{CB}_{1}$ receptors and adenosine $A_{2 A}$ displays a striking $G$ protein-coupling signaling profile where the stimulation of both receptors reduces the downstream signaling (Moreno et al, 2017); (ii) the formation of heteromers between $\mathrm{CB}_{1}$ receptors and D2 receptors changes the agonist-mediated $\mathrm{CB}_{1}$ receptor signaling and coupling (Bagher et al, 2016). More research is needed to better understand the functional impact of the formation of homomers or heteromers between $\mathrm{CB}_{1}$ receptors and other brain receptors in physiology and pathology.

Besides GPCR homo- or heterodimerization, other $\mathrm{CB}_{1}$ interacting proteins have been identified (Smith et al, 2010), which can greatly determine differential $\mathrm{eCB}$ signaling in the brain. For instance, the cannabinoid receptor-interacting protein 1A (CRIP1A) has been proposed as one of the examples of interacting proteins that can modify $\mathrm{CB}_{1}$ receptor signaling (Blume et al, 2017; Niehaus et al, 2007). This can have important functional implications, because CRIP1A is present in specific brain cell types (Guggenhuber et al, 2015; Smith et al, 2015). For instance, CRIP1A is coexpressed with $\mathrm{CB}_{1}$ receptors in pyramidal neurons and in a subpopulation of GABAergic interneurons in the hippocampus (Guggenhuber et al, 2015), thereby likely determining the ability of eCBs to regulate excitatory and inhibitory 
neurotransmission in specific cell subpopulations. However, CRIP1A is also present in cells such as dentate granule cells or other cell types where $\mathrm{CB}_{1}$ receptors are likely not expressed (Smith et al, 2015), indicating that this protein might have additional functions in the brain.

\section{Same Receptor, Different Repertoire of G Proteins?}

The identification and discovery of $\mathrm{CB}_{1}$ receptors finds its roots in the observation that exogenous cannabinoids are able to specifically modulate cAMP levels in cultured cells (Howlett, 1984, 1987; Howlett et al, 2002). Thus, the first G protein-dependent pathway described for $\mathrm{CB}_{1}$ receptor signaling posited an inhibition of adenylyl cyclase (AC) activity through activation of $\mathrm{G}_{\mathrm{i} / \mathrm{o}}$ proteins. Early studies added the AC-dependent or -independent regulation of specific ion channels and, importantly, the impact of $\mathrm{CB}_{1}$ receptor signaling on other intracellular cascades, such as MAP kinases and others (for extensive review, see Howlett (2005); Nogueras-Ortiz and Yudowski (2016)). The exclusive coupling of $\mathrm{CB}_{1}$ receptors with $\mathrm{G}_{\mathrm{i} / \mathrm{o}}$ proteins was challenged years ago, when an interesting functional interplay between $\mathrm{CB}_{1}$ and dopamine $\mathrm{D} 2$ receptors was identified, indicating that their functional and/or physical interaction is able to switch $\mathrm{CB}_{1}$ receptor signaling from $\mathrm{G}_{\mathrm{i} / \mathrm{o}}$ to $\mathrm{G}_{\mathrm{s}}$ (Glass and Felder, 1997; Kearn et al, 2005). Considering that $\mathrm{CB}_{1}$ and D2 receptors are co-expressed in a limited subpopulation of brain neurons (in basal ganglia and other brain regions (Hermann et al, 2002; Marsicano and Kuner, 2008)), this can be considered as one of the first examples of an emerging property of cannabinoid signaling: the presence of active or inactive D2 receptors determines the outcome of $\mathrm{CB}_{1}$ receptor stimulation.

Earlier studies demonstrated how neurotransmission could be modulated by $\mathrm{CB}_{1}$ receptors through the inhibition of calcium channels independently of cAMP, suggesting direct G protein-dependent mechanisms (Mackie and Hille, 1992; Twitchell et al, 1997). Moreover, adding a bit more complexity to the picture, recent work indicates that the $\mathrm{G}$ protein coupling of $\mathrm{CB}_{1}$ receptors definitely extends far beyond $\mathrm{G}_{\mathrm{i} / \mathrm{o}}$. For instance, whereas the presynaptic control of neurotransmitter release in neurons is compatible with an inhibitory effect on AC signaling, it was recently shown that blockade of $\mathrm{G}_{\mathrm{i} / \mathrm{o}}$ in the globus pallidus can switch the effect of $\mathrm{CB}_{1}$ receptors toward activation of $\mathrm{G}_{\mathrm{s}}$ and potentiation of neurotransmission (Caballero-Floran et al, 2016). In this sense, early studies also showed how $\mathrm{CB}_{1}$ receptors can couple to $G_{s}$, demonstrating the signaling complexity of $C_{1}$ receptors (Glass and Felder, 1997). Another clear example of multiple $\mathrm{CB}_{1}$-dependent $\mathrm{G}$ protein signaling is in astrocytes. In this cell type, activation of $\mathrm{CB}_{1}$ receptors increases intracellular calcium, which is likely mediated by $\mathrm{G}_{\mathrm{q}}$ proteins (Navarrete and Araque, 2008). Together with a previous work (Prather et al, 2000), a recent thorough study specifically aimed at identifying the $G$ proteins activated by $\mathrm{CB}_{1}$ receptors in the mouse cortex using a combination of
GTPgamma-binding assays coupled to specific immunoprecipitation with antibodies against different subtypes of $G$ proteins (Diez-Alarcia et al, 2016). The results clearly identified specific $C_{1}$ receptor coupling with different subunits of the classic inhibitory $\mathrm{G}_{\mathrm{i} / \mathrm{o}}$, but also with $\mathrm{G} \alpha_{\mathrm{z}}$, $\mathrm{G} \alpha_{\mathrm{q} / 11}$, and $\mathrm{G} \alpha_{12 / 13}$ (Prather et al, 2000; Diez-Alarcia et al, 2016). Interestingly, Diez-Alarcia and colleagues (2016) observed biased signaling patterns depending on the cannabinoid used, suggesting not only that $\mathrm{CB}_{1}$ receptors can couple to different $G$ proteins but also that different endogenous or exogenous ligands might preferentially direct the signaling toward specific pathways. Given that $\mathrm{CB}_{1}$ receptors expressed in different cell types in the brain have differential effects (Busquets-Garcia et al, 2015), we suggest that this heterogeneity in $G$ protein coupling by $\mathrm{CB}_{1}$ receptors and the associated biased actions of specific agonists is at least partially due to cell-type-specific expression of the receptor. It would be extremely interesting to test whether the $G$ protein activation patterns might be altered, possibly in a cell-type-dependent manner, under different physiological or pathological conditions. Indeed, as mentioned above, pathophysiological conditions such as stress or excessive neuronal activity markedly alter $\mathrm{CB}_{1}$ receptor signaling. Future studies will address these new possibilities, potentially making the brain ECS one of the first targets of a new signaling- and/or cell-type-specific pharmacology, which will be essential for interventional therapies against neurological and psychiatric disorders.

\section{Beyond G Protein Signaling}

Besides the regulation of $\mathrm{G}$ protein signaling, $\mathrm{CB}_{1}$ receptors also activate $\beta$-arrestin 1 and 2 , which mediate their internalization (Raehal and Bohn, 2014; Turu and Hunyady, 2010), and trigger other intracellular pathways, such as activation of MAPK (Rozenfeld and Devi, 2008). Interestingly, $\beta$-arrestin 1 pathways are likely $\mathrm{G}$ proteinindependent (Ahn et al, 2013). Although the respective roles of $\mathrm{G}$ proteins, $\beta$-arrestin 1 and $\beta$-arrestin 2 need to be further clarified, the activation of $\mathrm{CB}_{1}$ receptors in the brain results in two major downstream effects, namely the regulation of ion channels and of intracellular kinases, which have been reviewed extensively (Freund et al, 2003; Howlett, 2005; Howlett et al, 2002; Howlett et al, 2004; Lu and Mackie, 2016). Briefly, $\mathrm{CB}_{1}$ receptors can inhibit $\mathrm{N}$ - and P/Q-type $\mathrm{Ca}^{2+}$ channels, activate different types of $\mathrm{K}^{+}$channels and promote phosphorylation of extracellularly regulated kinases (ERKs). More recently, experiments on retinal ganglion cell revealed that $\mathrm{CB}_{1}$ receptor activation can lead to the AMPactivated kinase-dependent inhibition of the $\mathrm{Na}-\mathrm{K}-\mathrm{Cl}$ cotransporter (NKCC1) activity, eventually reducing intracellular levels of $\mathrm{Cl}^{-}$(Miraucourt et al, 2016).

The inhibition of $\mathrm{AC}$ activity by $\mathrm{CB}_{1}$ receptor recruitment of $G_{i / o}$ proteins leads to a decrease in the levels of cAMP (Howlett et al, 2002) and consequently of the activity of the protein kinase A (PKA). G protein-dependent or -independent mechanisms link cannabinoid actions to the activation 
of ERK and FAK kinases (Ahn et al, 2013; Derkinderen et al, 1996; Derkinderen et al, 2003). Recent evidence points to the idea that $\mathrm{CB}_{1}$ receptors can activate the main target of rapamycin (mTOR) pathway, a key intracellular signaling regulating protein synthesis and synaptic plasticity (CostaMattioli and Monteggia, 2013; Laplante and Sabatini, 2012; Puighermanal et al, 2009). Notably, recent findings showed that $\mathrm{CB}_{1}$ receptor activation enhances protein synthesis via the mTOR pathway that control presynaptic local protein synthesis to modulate neurotransmitter release during brain long-term plasticity (Younts et al, 2016). Interestingly, the improvement of several behavioral abnormalities observed in a mouse model of fragile $\mathrm{X}$ syndrome by blockade of $\mathrm{CB}_{1}$ receptors is linked to the decreased activation of hippocampal mTOR signaling (Busquets-Garcia et al, 2013).

\section{Subcellular Signaling of $\mathrm{CB}_{1}$ Receptors: Just on Plasma Membranes?}

GPCRs, such as $\mathrm{CB}_{1}$ receptors, are classically seen as plasma membrane proteins located in the optimal position to convert extracellular signals into intracellular responses (Figure 1). Indeed, a high-school student consulting Wikipedia or the Encyclopedia Britannica for a homework project on GPCRs would find these definitions, respectively: 'GPCRs are proteins that detect molecules outside the cell and activate internal signal transduction pathways and, ultimately, cellular responses' (https:/en.wikipedia.org/wiki/ G_protein\%E2\%80\%93coupled_receptor), or '[GPCR is a] protein located in the cell membrane that binds extracellular substances and transmits signals from these substances to an intracellular molecule called a G protein' (https://www. britannica.com/science/G-protein-coupled-receptor). The plasma membrane position, optimal to 'detect molecules outside the cell' has been demonstrated by a multitude of ultralocalization and functional studies. Indeed, most of the classical knowledge on GPCR biochemistry and biophysics derives from seminal studies on beta-adrenergic receptors (www.nobelprize.org, 2014), which detect adrenalin, a watersoluble hormone. However, the idea that GPCRs are present only at the plasma membrane has been challenged over the years by elegant studies, showing that different types of GPCRs can be functionally located inside the cell (Irannejad et al, 2017; Irannejad et al, 2013; Jong et al, 2014; Tsvetanova et al, 2015; for review: Khan et al, 2016; Jalink and Moolenaar, 2010). If this is true for GPCRs targeted by water-soluble ligands, it might be even more likely for lipid receptors. Indeed, the largest class of GPCRs in mammals is represented by odor receptors that are generally volatile compounds that dissolve well in organic solvents but have low solubility in water-based media (Forss, 1972). The $\mathrm{CB}_{1}$ receptor is primarily a lipid receptor: the recent interesting discovery of a novel class of cannabinoid peptides considered negative allosteric modulators of $\mathrm{CB}_{1}$ receptor (pepcans (Bauer et al, 2012; Hofer et al, 2015)) aside, the large majority of plant-derived, synthetic, and endogenous arachidonic acid derivatives eCBs are lipids. Despite the clear differences between water-soluble and -insoluble ligands, we lack a comprehensive understanding of the specific features of GPCRs targeted by lipids. One important difference may be how the ligand reaches the receptor. In this context, there is now evidence that eCBs access the binding pocket of $\mathrm{CB}_{1}$ receptor via the lipid bilayer, suggesting that ligand entry via a lipid portal is quite likely for this GPCR (Hurst et al, 2010; Hurst et al, 2013; Reggio, 2010). Consistent with this idea, exogenous cannabinoids appear to rely on lateral diffusion through the membrane lipid bilayer to reach their binding sites on $\mathrm{CB}_{1}$ and $\mathrm{CB}_{2} \mathrm{Rs}$ (Kimura et al, 2009). Although further studies are necessary, the recent analyses of the crystal structure of the CB1 receptor protein (Hua et al, 2016; Shao et al, 2016; Hua et al, 2017) is compatible with and provide further information on this peculiar binding path of lipid cannabinoids, which implies that these compounds can easily move within cellular membranes. Indeed, a consolidated vision of lipid cellular organization suggests that eukaryotic cell membranes form a sort of unique entity, called the endomembrane system (Morré and Mollenhauer, 1974), within which lipids can easily move either via active or passive mechanisms (Voelker, 1991). Interestingly, early studies showed that many lipid molecules undergo rapid transport amongst different cellular membranes (Voelker, 1991). In certain situations, the access to intracellular compartments might be even easier for eCBs. Although more research is needed, it is interesting to note here that lipid eCBs are produced and degraded within both the plasma membrane and organelle membranes inside cells (Gulyas et al, 2004; Morozov et al, 2004). For example, the fatty acid amide hydrolase (FAAH) enzyme, which degrades the eCB anandamide (AEA), is present in intracellular membrane constituents (eg, in mitochondria; Morozov et al, 2004). Similarly, monoacylglycerol lipase (MAGL), the degrading enzyme of 2-arachidonoyl-glycerol (2-AG), the other major lipid eCB also seems to be present in subcellular compartments (Blankman et al, 2007). In agreement with these localization studies, biochemical assays indicate that 2$A G$ and AEA are present in intracellular purified brain mitochondria and that the dual inhibitor of FAAH and MAGL JZL195 increases eCBs in isolated mitochondria, thereby modulating mitochondrial respiration (Benard et al, 2012) (see also below).

In addition to the $\mathrm{eCB}$ degradative enzymes, there is also evidence supporting the presence of intracellular $\mathrm{CB}_{1}$ receptors. Early anatomical studies revealed that a large proportion of $\mathrm{CB}_{1}$ receptors in brain cells are intracellular (Freund et al, 2003). However, given that GPCRs were believed to be functional only at plasma membranes, the presence of intracellular $\mathrm{CB}_{1}$ receptors was exclusively interpreted as 'trafficking' proteins, caught in the process to be transported to or recycled from their 'natural' functional location, the plasma membrane (Freund et al, 2003). Altogether, these observations revealed that the constituent pieces of the ECS are present inside cells and set the stage for more recent studies demonstrating a 


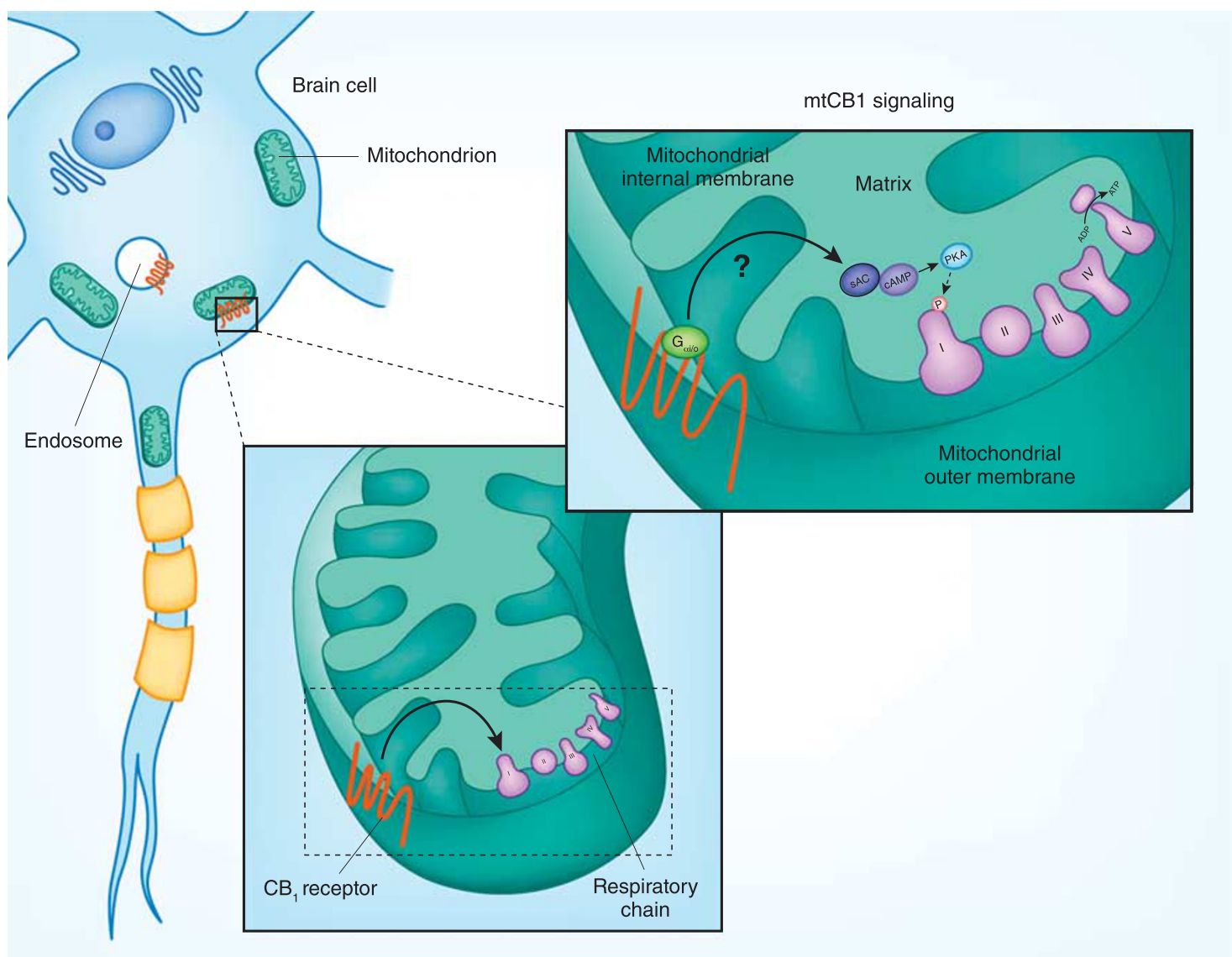

Figure 2. Schematic view of the $\mathrm{mtCB}_{1}$-dependent signaling pathway. $\mathrm{CB}_{1}$ receptors are present in brain mitochondria likely in the external membrane where they regulate the respiratory chain and ultimately the mitochondrial functions (eg, ATP production). On the right, we represented the signaling pathway downstream $m \mathrm{mCB}_{1}$ receptors. It has been described that $\mathrm{mtCB}_{1}$ receptors mediate its effects involving intra-mitochondrial $\mathrm{G}_{\mathrm{i} / \mathrm{o}}$ protein signaling, mitochondrial CAMP synthesis that is catalyzed by a soluble form of adenylyl cyclase (SAC), and the decrease of intra-mitochondrial PKA activity that also reduced phosphorylation of specific subunits of complex I (eg, NDUFS2). All these events can impair the respiratory chain decreasing mitochondrial respiration, likely affecting other mitochondria functions. For additional information refer to the main text.

functional role for intracellular $\mathrm{CB}_{1}$ receptor signaling in brain functions.

One of the first pieces of evidence for the presence of intracellular cannabinoid signaling came from the observation that cannabinoids can activate $\mathrm{CB}_{1}$ receptors localized in late endosomal/lysosomal compartments (Thibault et al, 2013), where they can trigger $G$ protein-dependent signaling (Rozenfeld and Devi, 2008). Accordingly, a recent study showed how a $\beta$-arrestin-mediated signaling from $\mathrm{CB}_{1}$ receptors could modulate the endocytic trafficking (Delgado-Peraza et al, 2016). Perhaps the most complete evidence so far for intracellular functional cannabinoid signaling relies on the presence of $\mathrm{CB}_{1}$ receptors on mitochondrial membranes. Already in the Seventies of last century, different studies reported effects of cannabinoids on mitochondria, including decrease of complex I or V activities and changes in mitochondrial ultrastructure (Bartova and Birmingham, 1976; Bino et al, 1972; Chari-Bitron and Bino, 1971; Mahoney and Harris, 1972; Schurr and Livne, 1975). These effects remained unexplained and, with the identification of $\mathrm{CB}_{1}$ receptors as typical plasma membrane GPCRs, they were ascribed to unspecific alterations of mitochondrial membrane properties by lipid molecules (Bartova and Birmingham, 1976; Howlett et al, 2002) or to indirect $\mathrm{CB}_{1}$ receptor-dependent signaling (Campbell, 2001).

However, in 2012, electron microscopic immunogold experiments accompanied by controlled functional assays revealed that a small but significant proportion of hippocampal $\mathrm{CB}_{1}$ receptors are localized at mitochondrial membranes (called $\mathrm{mtCB} 1$ ), where they mediate reduction of $\mathrm{O}_{2}$ consumption by exogenous and endogenous cannabinoids (Benard et al, 2012). Interestingly, similar mitochondrial localization of $\mathrm{CB}_{1}$ receptors has been also shown in peripheral tissues, such as sperm cells (Aquila et al, 2010) and muscles, where the proportion of $\mathrm{mtCB}_{1}$ receptors appears to be higher than in the brain (Mendizabal-Zubiaga et al, 2016). The signaling of $\mathrm{mtCB}_{1}$ receptors in the brain started to be deciphered. Pharmacological and genetic experiments showed that the effects of cannabinoids on mitochondrial respiration, cAMP levels, and PKA activity are blocked by pertussis toxin, suggesting an involvement of intra-mitochondrial $G_{i / o}$ protein signaling. Mitochondrial cAMP synthesis is catalyzed by a soluble form of AC (sAC), and manipulation of sAC activity also blocked the effects of 
cannabinoids on brain mitochondria. Moreover, a physical interaction between $\mathrm{G}$ proteins and sAC was identified in brain mitochondria, which was increased upon cannabinoid treatments, suggesting that $\mathrm{mtCB}_{1}$ signals through a $\mathrm{G}$ protein and $\mathrm{sAC}$-dependent intra-mitochondrial pathway. Following the consequent decrease of PKA activity, specific proteins of the OXPHOS chain (in particular of complex I) appear to be less phosphorylated possibly explaining the final effect on $\mathrm{O}_{2}$ consumption. Importantly, as mentioned below, genetic approaches showed that decreased intramitochondrial PKA activity and reduced phosphorylation of a specific subunit of complex I (NDUFS2) are necessary for specific effects of cannabinoids in vitro and in vivo (Hebert-Chatelain et al, 2016) (Figure 2).

The $\mathrm{mtCB}_{1}$-dependent intra-mitochondrial signaling cascade is far from being completely understood and presents surprising elements. In particular, it is notable that sAC is thought to be a G protein-independent form of AC (Buck et al, 1999; Chen et al, 2000). Indeed, sAC lacks key structural features that allow membrane-bound AC enzymes to interact with $G$ protein (Steegborn, 2014). Therefore, it is not clear yet how $\mathrm{mtCB}_{1}$ receptors could trigger the reduction of $\mathrm{O}_{2}$ consumption by brain mitochondria via an interaction between $\mathrm{G}$ proteins and sAC. It is possible that cell-type- or organelle-specific regulation of sAC activity exists, perhaps mediated by the formation of intramitochondrial signaling complexes. In other words, brain mitochondria may express unique complexes that induce the indirect interaction between $\mathrm{G}$ proteins and sAC. Consistent with this idea, recent reports demonstrate that sAC is involved in an endocytosis-dependent cAMP response suggesting that the link between GPCRs and sAC depends on a larger scaffolding complex and not just on the activation of GPCRs at the plasma membrane (Inda et al, 2016). Clearly, further studies are required to clarify this and other issues linked to the discovery of $\mathrm{mtCB}_{1}$ receptors. These should include efforts directed at identifying both the specific effects of cannabinoids on mitochondrial functions and the potential impact these GPCR-mitochondrial interactions have on ECS function. Indeed, by regulating innumerous cellular processes beyond ATP production, mitochondria exert a plethora of functions that are particularly crucial for one of the most energy-avid organs of the body, such as the brain (Mattson et al, 2008).

\section{Endogenous Allosteric Modulation of $\mathrm{CB}_{1}$ Receptors}

$\mathrm{CB}_{1}$ receptors are endowed with important physiological and endogenous regulatory mechanisms able to enhance or limit their activity in the brain and in the body (Piazza et al, 2017). For instance, the endogenous anti-inflammatory lipid lipoxin A4 has been shown to be an allosteric enhancer of $\mathrm{CB}_{1}$ receptor signaling in the brain. In particular, the presence of lipoxin A4 is able to increase the affinity of $A E A$ at $C_{1}$ receptors, thereby potentiating the signaling and behavioral effects of this eCB. This mechanism likely has an important physiological role in the modulation of $\mathrm{CB}_{1}$ receptor signaling (Pamplona et al, 2012) and might have important behavioral consequences (see below).

Even more intriguing, recent studies showed that the neurosteroid pregnenolone is an allosteric signal-specific inhibitor of $\mathrm{CB}_{1}$ receptors, able to protect the brain from excessive cannabinoid intoxication (Vallee et al, 2014 but see also Krohmer et al, 2017; Khajehali et al, 2015). Pregnenolone has been long considered as the per se biologically inactive precursor of other steroids. Vallee et al (2014) showed that high doses of THC or other exogenous cannabinoids impressively increase the levels of pregnenolone in different brain regions. In turn, pregnenolone is able to decrease certain effects of cannabinoids (see below) by binding an identified allosteric site in the sequence of the $\mathrm{CB}_{1}$ receptor. Very importantly, pregnenolone does not inhibit, like an orthosteric antagonist, all signaling pathways triggered by $\mathrm{CB}_{1}$ receptor activation. Whereas the decrease of cAMP by cannabinoids is not altered by pregnenolone, the neurosteroid fully inhibits the $\mathrm{CB}_{1}$-dependent modulation of the ERK pathway and of mitochondrial functions (Vallee et al, 2014). This unique mode of action suggests that pregnenolone-derived drugs (more stable and better absorbed than pregnenolone itself) can be used to treat conditions characterized by excessive activation of $\mathrm{CB}_{1}$ receptors (Piazza et al, 2012; Vallee et al, 2014). Indeed, after completing preclinical studies showing very interesting properties, clinical trials are running at the moment of writing, aimed at testing the efficacy of a pregnenolone derivative (AEF0117) on cannabis addiction.

Whereas the origin of lipoxin A4 in the brain is not fully elucidated, pregnenolone is produced, like all steroids, by cell mitochondria. Considering that high levels of eCB $s$ have been implicated in the activation of $\mathrm{mtCB}_{1}$ receptors (Benard et al, 2012), it is tempting to speculate that a subcellular mechanism might underline the negative feedback actions of pregnenolone. In this sense, activation of $\mathrm{CB}_{1}$ receptors (possibly directly at mitochondrial membranes) might stimulate the production of pregnenolone to partially inhibit $\mathrm{CB}_{1}$ signaling in the same subcellular compartment, same cell, and/or in neighboring ones. If confirmed by experimental evidence, this would be a very interesting and sophisticated example of autocrine/paracrine self-control of a receptor system in the brain. In this context, it is also important to mention the recent identification of pepcans, a family of endogenous peptides proposed to exert allosteric regulation of CB1 receptors (Bauer et al, 2012).

\section{SYNAPTIC FUNCTIONS OF THE ECS: EXTRACTING SPECIFICITY FROM UBIQUITY}

It is clear that the machinery required for the production of eCBs is located at synapses. This means that eCBs release occurs at, or very close to, synaptic sites. For example, at hippocampal glutamate synapses, the 2-AG synthesizing enzyme, DGL- $\alpha$, is highly accumulated in nanodomains in 
the perisynapse region (Katona et al, 2006). Similar nanodomain localization has been described in some regions of the cortex and amygdala between CCK-positive basket cells and their targets (Omiya et al, 2015). Intriguingly, the basket cells express the vesicular glutamate transporter (vGluT3) at some, but not all their synapses. Thus, postsynaptic elements opposing vGluT3 express DGL- $\alpha$ (Omiya et al, 2015 but see also Yoshida et al, 2011), suggesting a link between vGluT3 functions and eCB production, which implies selective regulation of $\mathrm{eCB}$ signaling at different synapses of the same neuron.

What remains unclear, however, is whether each synaptic site is regulated independently of another site. One of the key features of synapses is that they offer relatively private and privileged communication between one presynaptic element and its postsynaptic partner. eCBs, however, are likely liberated from all sites of production in response to a postsynaptic depolarization. In this sense, as eCBs can be released following GPCR activation (eg, mGLUR5, muscarinic receptors), these molecules can be considered as a coincidence detector of depolarization and GPCR activation (Kano et al, 2009). Of course, there will be some decay of the depolarization that will mean release at distant sites is less likely to occur, but this spatial gradient approach to neuronal signaling is curious. By contrast, once mobilized, the spread of the eCBs is very tightly controlled as shown by the demonstration that liberation of eCBs from one pyramidal neuron does not have any effect on $\mathrm{CB}_{1}$ receptors at synapses on a neighboring neuron (Younts et al, 2013). However, in this study, the theta burst stimulation used was not able to activate $\mathrm{CB}_{1}$ receptors on Schaffer collaterals to produce long-term depression (LTD). As mentioned above, this can be caused by the highly specialized basket cell synapses onto CA1 pyramidal neurons (Omiya et al, 2015; Yoshida et al, 2011).

Indeed, all cells examined so far are capable of producing eCBs that, in turn, can exert biological effects. Yet, the highly specific localization of $\mathrm{CB}_{1}$ receptors, their differential signaling effects, the strong dependence of these effects on neuronal circuit activity, and the strong temporal regulation of eCB mobilization indicate that this ostensibly unspecific mode of action is, in fact, highly regulated.

At the cellular, or synaptic level, eCBs have been conceptualized as 'circuit breakers' (Katona and Freund, 2008,2012). This view is derived from a vast literature showing that once liberated from the postsynaptic cell, eCBs act on presynaptic $\mathrm{CB}_{1}$ receptors to decrease the probability of release. Although this review is focused on $\mathrm{CB}_{1}$ receptors, some works identified TRPV1 channels as an additional player in this concept of circuit breaker suggesting a more complex scenario (Puente et al, 2011; Chávez et al, 2010). Yet, linking this circuit breaker function to the output of a neural network, let alone behavior, has remained elusive. Are there pieces of the $\mathrm{eCB}$ puzzle that remain hidden? (likely). Are we over-simplifying, to make convenient links between what we currently know at the microscopic level, to what we know at the macroscopic level? (perhaps). How do we begin to bridge the divide to make a more explicit link between synaptic/cellular signaling and behavior? In an attempt to solve this complex puzzle, and before entering into the behavioral aspects, we will discuss different synaptic concepts including 'on demand' and 'tonic' activity of the ECS, specific mechanisms of eCB mobilization, the synaptic role of $\mathrm{CB}_{1}$ receptors in astrocyte, or the role for postsynaptic $\mathrm{CB}_{1}$ receptors.

\section{Circuit Breakers and Synaptic Discriminators}

eCBs exert the majority of their known actions by directly targeting $\mathrm{CB}_{1}$ receptors located on presynaptic nerve terminals. Many outstanding research papers and reviews have been written describing how either depolarization of the postsynaptic neuron or activation of GPCRs can liberate eCBs. Information about this can be found in several excellent reviews (Castillo et al, 2012; Freund et al, 2003; Kano et al, 2009; Katona and Freund, 2012; Piomelli, 2003; Araque et al, 2017) and will not be covered in detail here. Briefly, these molecules, either 2-AG or anandamide, are produced at postsynaptic level, traverse the synaptic cleft, and bind to presynaptic $\mathrm{CB}_{1}$ receptors. These GPCRs act either directly on vesicular release machinery or at $\mathrm{Ca}^{2+}$ channels to decrease the probability of neurotransmitter release (Pr). The simple take-away message is that eCBs weaken synaptic connections, effectively functioning as very efficient, synaptic 'circuit breakers' (Katona and Freund, 2008). The circuit breaker concept emerges from early findings that deletion of $\mathrm{CB}_{1}$ receptors exclusively from excitatory neurons causes hyperexcitability and predisposes the brain to epileptic-type seizures (Marsicano et al, 2003; Monory et al, 2006). As a breaker in an electrical circuit protects the circuit from a power surge, 2-AG acting at presynaptic $\mathrm{CB}_{1}$ receptors on glutamate terminals appears to protect, through a negative feedback, from excessive excitatory neurotransmission. Moreover, several observations indicated that there may be additional nuances that should be considered. First, as eCBs, like 2-AG, are mobilized from multiple synapses during depolarization of the postsynaptic cell, they will impact numerous inputs (provided that these inputs express functional $\mathrm{CB}_{1}$ receptors). This means that in some brain regions, both excitatory and inhibitory transmission will be affected (Wamsteeker et al, 2010b). If the neuronal output is simply an algebraic sum of excitatory and inhibitory synaptic inputs, then it is difficult to envision how this scenario would alter network activity. Clearly, there are additional elements that must be considered. In some systems, $\mathrm{CB}_{1}$ receptor expression is biased toward GABA synapses, rather than glutamate synapses (Katona and Freund, 2012), suggesting that specificity of eCB signaling lies in the differential expression of $\mathrm{CB}_{1}$ receptors on nerve terminals. Specificity could also result from highly regionalized mechanisms that control the spread of eCBs from one synapse to another (Younts et al, 2013), but how exactly this is regulated is not clear. An alternate view is that eCBs, by decreasing $\mathrm{Pr}$, create a scenario whereby inputs originating from neurons that spike at particular rates are favored (Foldy et al, 2006). For 


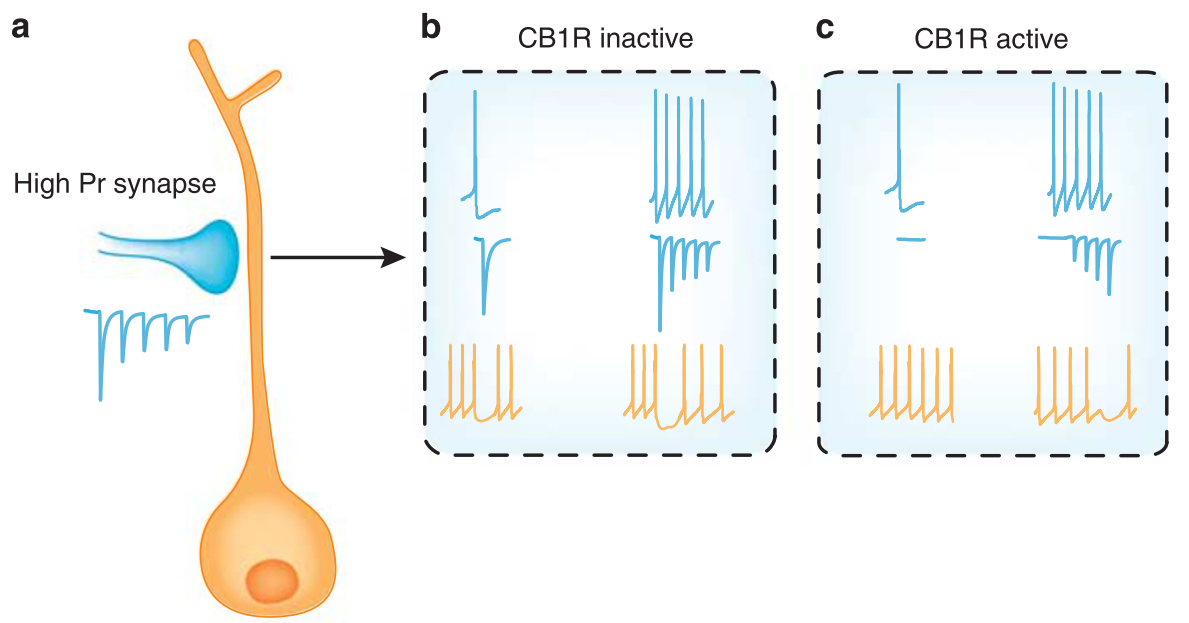

d

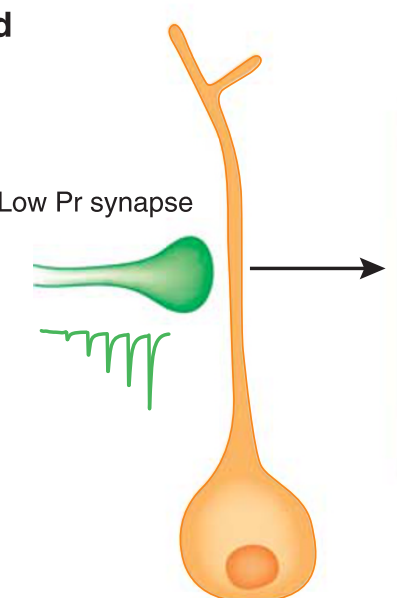

e

f

CB1R inactive

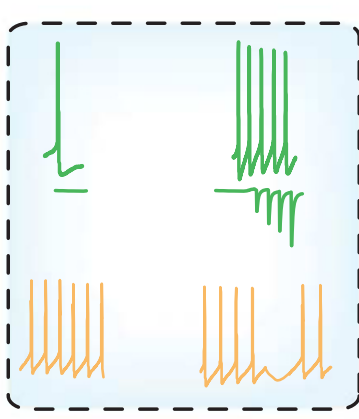
CB1 $\mathrm{R}$ active

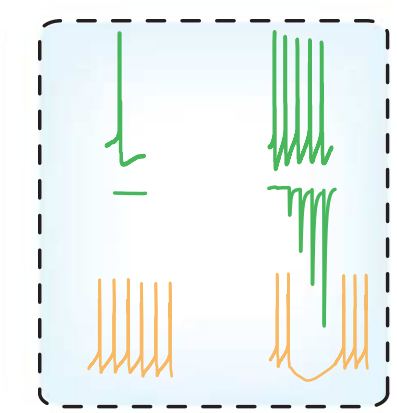

Figure 3. $\quad \mathrm{CB}_{1}$-mediated effects, release probability, and presynaptic activity on postsynaptic firing. (a) Schematic depiction of a GABA synapse (blue) that has a high initial release probability. With rapid, repeated activation of the presynaptic neuron, GABA release decreases. (b) Blue traces show the spike patterns in the presynaptic neuron and the putative synaptic response immediately below in a condition when $\mathrm{CB}_{1}$ receptors are not recruited. In orange, the activity of postsynaptic neuron and the effect of the inhibitory event. Note that a single presynaptic action potential is sufficient to elicit a pause in firing of the postsynaptic neuron. A burst of presynaptic action potentials elicits a pause that is marginally longer, but rapid synaptic depression allows postsynaptic firing to resume quickly. (c) When $\mathrm{CB}_{1}$ receptors are recruited, a single action potential evokes no release and consequently, postsynaptic firing is unaffected. A burst of presynaptic action potentials, however, results in synaptic facilitation and a prolonged pause in postsynaptic firing. (d) Schematic depiction of a GABA synapse (green) that has a low initial release probability. With rapid, repeated activation of the presynaptic neuron, GABA release increases. (e) Green traces show the spike patterns in the presynaptic neuron and the putative synaptic response immediately below in a condition when $\mathrm{CB}_{1}$ receptors are not recruited. In orange, the activity of postsynaptic neuron and the effect of the inhibitory event. Note that a single presynaptic action potential has no effect on firing of the postsynaptic neuron. A burst of presynaptic action potentials results in synaptic currents that facilitate and cause a delayed pause in firing of the postsynaptic neuron. (f) When $\mathrm{CB}_{1}$ receptors are recruited, a single action potential still evokes no release and again, postsynaptic firing is unaffected. A burst of presynaptic action potentials, however, results in very profound synaptic facilitation and a prolonged pause in postsynaptic firing.

example, decreasing Pr does weaken synapses when assessed as the response to a single presynaptic action potential. The decrease in Pr, however, also means that during a train of action potentials, synapses can facilitate more readily, resulting in an increase, rather than a decrease in synaptic strength. This has been demonstrated in hypothalamus where blockade of $\mathrm{CB}_{1}$ receptors increases $\mathrm{Pr}$ at GABA synapses, but weakens inhibition to the postsynaptic neuron when GABA inputs are recruited at a high frequency (Oliet et al, 2007). This suggests that $\mathrm{CB}_{1}$ receptors at some synapses may have some basal or constitutive signaling, even in the absence of ligand (Lee et al, 2015). Alternatively, local depolarization via kainate receptors (Lourenco et al, 2010) could be a critical regulator of this tonic $\mathrm{CB}_{1}$ receptor activity. In addition, as eCBs decrease the release of quantal events (in the absence of action potentials in the nerve terminal), they may further act to filter specific inputs by increasing the ratio of signal to noise. This suggests that in addition to their role as circuit breakers, eCBs are synaptic discriminators that promote selective communication between neurons at higher frequencies (Figure 3).

The scenario outlined above paints the presynaptic neuron as a passive element that is influenced by eCBs if $\mathrm{CB}_{1}$ receptors are present. A number of reports, however, suggest that the presynaptic neuron can dynamically regulate the expression/function of $\mathrm{CB}_{1}$ receptors. For example, repeated 
activation of GABA neurons or synapses in the hippocampus increases the efficacy of $\mathrm{CB}_{1}$ receptors on those terminals (Chen et al, 2007; Chen et al, 2003; Foldy et al, 2006; Heifets et al, 2008; Zhu and Lovinger, 2007), resulting in more robust DSI. Even the inhibition by $\mathrm{CB}_{1}$ receptors of GABA release can be overcome by increasing the firing rate of these cells (Foldy et al, 2006). The mechanistic link between repeated activation and changes in functional signaling of $\mathrm{CB}_{1}$ receptors remains unclear. One possibility is that like other GPCRs at presynaptic terminals (Kuzmiski et al, 2009; Pelkey et al, 2005), there may be activity-dependent insertion of $\mathrm{CB}_{1}$ receptors that relies on $\mathrm{Ca}^{2+}$-dependent fusion of vesicles containing the receptors. Alternatively, repeated activity may recruit intracellular signaling pathways that either, 'switch on' or 'switch off $\mathrm{CB}_{1}$ receptors. For example, in the hippocampus, activity-induced recruitment of calcineurin is crucial for amplifying eCB-mediated LTD at GABAergic synapses (Castillo et al, 2012). Moreover, as decreases in cell surface receptor mobility appear to be an important component of desensitization of $\mathrm{CB}_{1}$ receptors (Mikasova et al, 2008), it is conceivable that repeated activity reverses this process, thereby increasing the pool of receptors available to bind the ligand. Finally, in the CA1, presynaptic kainate receptors appear to have a key role in enhancing $\mathrm{CB}_{1}$ receptor function. Here it is proposed that local depolarization, driven by cation influx through the KAR, is sufficient to enhance $\mathrm{CB}_{1}$ receptor-dependent signaling (Lourenco et al, 2010). These observations indicate that entraining synapses with patterns of activity may be an effective way to up- or downregulate $\mathrm{CB}_{1}$ receptor function. This idea has been extended beyond the experimental brain slice preparation with the demonstration that electroconvulsive seizures and specific experiences that increase neuronal activity can rapidly increase the functional expression of $\mathrm{CB}_{1}$ receptors (Wamsteeker Cusulin et al, 2014; Wamsteeker et al, 2010b).

\section{Beyond Retrograde Signaling}

Although eCBs are known primarily as retrograde signals, their capacity to influence brain function is not limited to actions on nerve terminals. Some years ago, it was described how eCBs released from the dendrites of depolarized cerebellar neurons could inhibit nearby cells suggesting that eCBs, through the interneuron arborization, can regulate synaptic inputs far beyond its own limits of diffusion (Kreitzer et al, 2002). Moreover, there is now clear evidence that the eCBs also act on postsynaptic neurons as well as neighboring astrocytes (as noted above) (Figure 1). The first observations that eCBs can affect neuronal activity through mechanisms that do not rely on changes in synaptic function were described over a decade ago in the cortex (Bacci et al, 2004). This autocrine feedback through which eCBs elicit a slow hyperpolarization that inhibits neuronal activity provides a powerful way to regulate neuronal activity. Even though this concept of direct inhibition provides an elegant mechanism for linking cellular activity and behavior, there have been few descriptions of similar mechanisms in other brain regions. Whether this does, indeed, reflect a regionspecific phenomenon or merely highlights the need for more careful investigation in other brain regions remains unknown. A recent report demonstrates that $\mathrm{eCBs}$ act in an autocrine fashion in midbrain dopamine neurons to increase neuronal activity through a non- $\mathrm{CB}_{1}$ receptor-mediated mechanism (Gantz and Bean, 2017). Here the target of eCBs is not $\mathrm{CB}_{1}$ receptors, but A-type potassium channels. Accordingly, previous works have shown how eCBs could affect the functioning of other channels in a $\mathrm{CB}_{1}$ receptorindependent manner such as TRPV1, GABA-A, nicotinic, or glycinergic channels (Zygmunt et al, 1999; Sigel et al, 2011; $\mathrm{Oz}$ et al, 2003; Xiong et al, 2012). Specifically, 2-AG appears to act directly on the rapidly activating and inactivating $\mathrm{K}$ channels to increase neuronal activity. These disparate observations indicate that the actions of eCBs are regionand cell-type-specific, and highlight the importance of conducting additional experiments extending the focus of investigators beyond the nerve terminal. Consistent with this idea are recent observations demonstrating that eCBs, through actions on postsynaptic $\mathrm{CB}_{1}$ receptors, drive a non-canonical signaling mechanism that recruits c-Jun$\mathrm{N}$-terminal kinases (JNKs) and nitric oxide (Maroso et al, 2016). In this recent study, the authors described how the activation of a specific pool of postsynaptic CB1 receptors increases a hyperpolarization-activated $\mathrm{K}^{+}$current (Ih) that is present in the dendrites of a subset of hippocampal pyramidal neurons in the superficial layers. Ih has a key role in integrating coincident synaptic signals in the dendrites and the authors show that this decrease in the integration of excitatory synaptic signals inhibits the induction of longterm potentiation and the formation of spatial memory.

An important issue concerning postsynaptic effects of eCB actions is the precise subcellular localization of the target receptors. For the moment, there is lack of anatomical evidence of postsynaptic $\mathrm{CB}_{1}$ receptors located at plasma membrane (Freund et al, 2003) (Figure 1) although it cannot be discarded that low levels of $\mathrm{CB}_{1}$ receptors below level of detection are present at this precise location. However, intracellular $\mathrm{CB}_{1}$ receptors, and in particular $\mathrm{mtCB}_{1}$, are clearly present both at presynaptic terminals and at somatodendritic compartments of glutamatergic and GABAergic hippocampal neurons (Benard et al, 2012) (Figure 1). It is, therefore, tempting to speculate that postsynaptic effects of eCB s might act intracellularly. Future studies will address this intriguing hypothesis.

As described above, recent data indicate that astrocytes are important additional players that express $\mathrm{CB}_{1}$ receptors and may affect neuronal/synaptic function. As explained earlier, although $\mathrm{CB}_{1}$ receptors are generally thought to be 'inhibitory' due to their coupling to $G_{i}$ proteins, this does not apply to all cell types and conditions. In astrocytes, $\mathrm{CB}_{1}$ receptors increase intracellular $\mathrm{Ca}^{2+}$, possibly through $\mathrm{G}_{\mathrm{q}}$ coupling (Navarrete and Araque, 2008). As a consequence, the present idea is that eCB-dependent activation of $\mathrm{CB}_{1}$ receptors in astrocytes can liberate gliotransmitters (Navarrete and Araque, 2008) that in turn act at neighbor 
or distant neurons (Han et al, 2012; Martin et al, 2015; Navarrete and Araque, 2008, 2010; Min and Nevian, 2012). This creates a scenario in which a postsynaptic pyramidal neuron not only decreases release probability $(\mathrm{Pr})$ at afferent neuronal synapses but it also signals to astrocytes to release gliotransmitters and activate other neurons (Araque et al, 2014; Gomez-Gonzalo et al, 2015; Navarrete and Araque, 2010; Araque et al, 2017).

In summary, synaptic effects of eCB signaling are emerging as more complex events as compared to what believed just few years ago, further extending the multifaceted ways through which this 'ubiquitous' system can modulate and determine very specific brain processes. How these novel mechanisms contribute to behavioral outcomes of ECS activity will be the subject of studies in the next decades. At the moment, the community is just starting to grasp the surface of this link, producing new mechanistic concepts and hypotheses, as we will touch upon in the next part of this article.

\section{NEW VIEWS ON BEHAVIORAL FUNCTIONS OF THE ECS}

The ECS impacts a plethora of behavioral functions. However, the picture of the underlying mechanisms is still incomplete. Besides the well-known inhibition of synaptic activity, new studies have revealed novel and surprising modes through which the ECS modulate animal behavior.

\section{Different Cells, Opposite Functions}

In addition to regulating molecular and synaptic functions in unexpected ways, the specific and differential localization of $\mathrm{CB}_{1}$ receptors in different cell types also has surprising behavioral consequences. Thus, $\mathrm{CB}_{1}$ receptors activated either by exogenous ligand or by eCBs in one particular cell type or another can have opposing effects on behavior. Indeed, if we dig into the eCB literature, we can find examples of how $\mathrm{CB}_{1}$ receptors located in different cellular subtypes such as GABAergic, glutamatergic, serotonergic, noradrenergic and other neurons, or astroglial cells can control different behavioral responses ranging from memory processes to food intake to stress. In this review, we will mention just a few interesting examples.

The specific genetic deletion of $\mathrm{CB}_{1}$ receptors from different cell types has been particularly important in helping us linking $\mathrm{CB}_{1}$ receptor expression in distinct cell types and different behavioral responses (see Busquets-Garcia et al, 2015 for specific examples). However, it is important to note that the possible role of $\mathrm{CB} 1$ receptors in regulating behavioral responses is highly state-dependent. Probably, the best-studied case is how $\mathrm{CB}_{1}$ receptors are key determinants of the biological balance between the excitatory glutamatergic and the inhibitory GABAergic neurons. Thus, $\mathrm{CB}_{1}$ receptor activation can lead to biphasic effects in food intake (Bellocchio et al, 2010; Hao et al, 2000) and anxiety (Rey et al, 2012), as well as novelty (Lafenetre et al, 2009) or fear fear responses (Metna-Laurent et al, 2012). Interestingly, acute pharmacological approaches in mutant and wild-type control mice indicate that $\mathrm{CB}_{1}$ receptor activation by low doses of the ligand impact glutamatergic transmission increasing food intake, producing anxiolytic-like effects, or favoring active fear responses, whereas higher doses affect GABAergic transmission decreasing food intake, increasing anxiety-like fear responses, or promoting passive fear responses, respectively (Bellocchio et al, 2010; MetnaLaurent et al, 2012; Rey et al, 2012).

The mechanisms underlying this differential recruitment of $\mathrm{CB}_{1}$ receptors on GABAergic or glutamatergic neurons remain unclear, and the full understanding of these biphasic effects of cannabinoid drugs and how the cell-type-specific expression of $\mathrm{CB}_{1}$ receptors mediates these effects is a big challenge for the future. As mentioned above, one potential explanation for these bimodal effects of cannabinoids is the possibility of cell-type-specific differences in the coupling of downstream intracellular signaling pathways (Steindel et al, 2013). In addition to this, the recently discovered biphasic effects of cannabinoids on the regulation of glucose intake by different brain regions (Miederer et al, 2017) may also rely on the differential expression of $\mathrm{CB}_{1}$ receptors in different cell types or subcellular compartments (see above).

However, the general picture is not as simplistic as understanding the effects of $\mathrm{CB}_{1}$ receptors on GABAergic or glutamatergic neurons. In addition to complex interactions between receptor signaling, changes in neurotransmitter release, and neuronal firing (discussed above), newly generated mutant mice and pharmacological studies have demonstrated the importance of $\mathrm{CB}_{1}$ receptors on the modulation of the dopaminergic (Bloomfield et al, 2016), noradrenergic (Busquets-Garcia et al, 2016), cholinergic (Soria-Gomez et al, 2015), or serotonergic (Dubreucq et al, 2012; Haring et al, 2015) systems, and their participation on the modulation of behavioral responses. Although it seems a utopic objective, the field must dedicate significant future work to combine these interesting findings in an effort to determine whether there is a more uniform set of rules that determine how $\mathrm{CB}_{1}$ receptors modulate behavior in a statedependent manner.

\section{Astroglial CB1 Receptors: Few of Them, but How Important?}

In the brain, $\mathrm{CB}_{1}$ receptor expression is not limited to neurons (Figure 1). In the last decade, it has been widely demonstrated that astrocytes can also express functional $\mathrm{CB}_{1}$ receptors (Bosier et al, 2013; Han et al, 2012; Navarrete and Araque, 2008, 2010). Although likely not all the astrocytes express $\mathrm{CB}_{1}$ receptors and the protein expression is difficult to detect by conventional light or fluorescent immunohistochemistry or by in situ hybridization approaches, RNASeq studies done in the cortex showed that about $20 \%$ of total $\mathrm{CB}_{1}$ receptor mRNA is present in astrocytes (https://web. stanford.edu/group/barres_lab/cgi-bin/igv_cgi_2.py?lname = CNR1). 
Moreover, it is well known that the expression levels of $\mathrm{CB}_{1}$ receptors on given cell types do not necessarily predict their functional relevance (Marsicano and Kuner, 2008) (ie, quantity is not quality). This fact becomes even more important when recent studies clearly demonstrated how the relatively small pool of astroglial $\mathrm{CB}_{1}$ receptors could control very complex processes, such as metabolic, electrophysiological, and behavioral responses (Bosier et al, 2013; Han et al, 2012; Navarrete and Araque, 2008, 2010; Min and Nevian, 2012).

However, the direct in vivo evidence for the role of astroglial CB1 receptors on behavior is relatively limited. The first observations came from the generation of mutant mice bearing a specific deletion of the $C B_{1}$ receptor gene in astrocytes (Han et al, 2012). These mice failed to exhibit the impairment of short-term working memory that is normally evident in mice given exogenous cannabinoids. This suggested that the activation of astroglial $\mathrm{CB}_{1}$ receptors is required for the working memory impairment induced by cannabinoids (Han et al, 2012). However, as the study of astroglial $\mathrm{CB}_{1}$ receptors is still nascent, the endogenous roles of these receptors on astrocytes and how precisely this impacts behavior need further investigation (Metna-Laurent and Marsicano, 2015; Oliveira da Cruz et al, 2016). Recent data in the striatum suggest that astroglial $\mathrm{CB}_{1}$ receptors might have a specific role in circuit selection processes (Martin et al, 2015). Thus, by determining the selective activity of particular circuits and likely contributing to the formation of selected functional neuronal 'domains', astroglial $\mathrm{CB}_{1}$ receptors can likely contribute to a fine modulation of behavioral responses. Moreover, $\mathrm{CB}_{1}$ receptors in astrocytes might also contribute to the modulation of memory processes via the regulation of adult neurogenesis (Sultan et al, 2015). Finally, another important aspect where astroglial $\mathrm{CB}_{1}$ receptors could have an important role is in the neuron-astrocyte metabolic coupling that has been shown to be also important for behavioral responses (Halassa and Haydon, 2010; Suzuki et al, 2011). Thus, the research community still has considerable work to do to dissect the specific roles of this relatively small but apparently important pool of $\mathrm{CB}_{1}$ receptors in modulating behavior both in physiological and pathological conditions.

\section{Memory Impact of Mitochondrial CB1 Receptors}

As discussed in the first part of this review, it is often early work that informs new ideas. In the 1970s, a number of reports demonstrated that cannabinoid drugs interfered with mitochondrial functions (Bartova and Birmingham, 1976; Bino et al, 1972; Chari-Bitron and Bino, 1971; Mahoney and Harris, 1972; Schurr and Livne, 1975), but this evidence was largely forgotten. There is now compelling evidence that $\mathrm{CB}_{1}$ receptors are present in mitochondrial membranes of different tissues (eg, brain, spermatozoa, and skeletal muscles) (Aquila et al, 2010; Benard et al, 2012; HebertChatelain et al, 2014; Koch et al, 2015; Mendizabal-Zubiaga et al, 2016) (Figure 3). Thus, the discovery of $\mathrm{CB}_{1}$ receptors on brain mitochondrial membranes paved the way to a novel field of research, dealing with the direct bioenergetic functions of GPCR signaling and their impact on behavior.

Recently, the first study showing the behavioral relevance of $\mathrm{mtCB}_{1}$ receptors was published (Hebert-Chatelain et al, 2016). This work indicates that acute cannabinoid-induced memory impairment in mice requires activation of hippocampal $\mathrm{mtCB}_{1}$ receptors. Genetic exclusion of $\mathrm{CB}_{1}$ receptors from hippocampal mitochondria prevents the cannabinoidinduced reduction of mitochondrial mobility, synaptic transmission, and memory formation (Hebert-Chatelain et al, 2016). Interestingly, hippocampal inhibition of $\mathrm{mtCB}_{1}$ signaling abolishes bioenergetic and amnesic effects of cannabinoids. Thus, the $\mathrm{G}$ protein-coupled $\mathrm{mtCB}_{1}$ receptors regulate memory processes via modulation of mitochondrial energy metabolism. Although these data reveal that acute bioenergetic processes are primary acute regulators of cognitive functions (Harkany and Horvath, 2017), more work is required to define the short- and long-term consequences of the decreased mitochondrial respiration and if similar mechanisms alter other behavioral responses. Recent data demonstrating that $\mathrm{mtCB}_{1}$ receptors are also likely involved on the regulation of food intake (Koch et al, 2015) suggest that there may be a growing role for these receptors in controlling various behavioral functions.

There is a robust literature focused on the impact of mitochondrial function or dysfunction in the brain relating to long-term pathological conditions (Cheng et al, 2010; Mattson et al, 2008; Picard, 2015; Raefsky and Mattson, 2017). On the other hand, very little is known about the direct impact of physiological regulation of mitochondrial activity on ongoing brain functions and behavior. Simply considering the fact that mitochondria-dependent processes such as controlling the levels of ATP (Rangaraju et al, 2014), the tight modulation of $\mathrm{Ca}^{2+}$ (Brini et al, 2014), or the generation of reactive oxygen species (Accardi et al, 2014) are absolutely necessary for normal synaptic transmission, it is very likely that slight adjustments of these mitochondrial functions through $\mathrm{mtCB}_{1}$ receptors could have deep and rapid impact on brain functioning and behavior. With the discovery of how this subcellular pool of $\mathrm{CB}_{1}$ receptors can modulate memory functions, a new path has already started linking cannabinoid signaling, mitochondria, and behavior. However, future studies will provide more information on how these organelles and their modulation by $\mathrm{CB}_{1}$ receptors are important for physiological and pathological behavioral responses.

\section{Endogenous Regulation of the ECS}

The ECS appears to trigger and regulate a very complex network of organ-, tissue-, and cell-specific signaling pathways, explaining the wide impact of $\mathrm{CB}_{1}$ receptor activation on many different behaviors. Just as a politician that with all the power but no control can lead an entire country into marked situations, $\mathrm{CB}_{1}$ receptor activity needs to be tightly controlled by brake mechanisms that can ultimately modify 
behavior (Piazza et al, 2017). As described in the first section of this review, these mechanisms include $\mathrm{CB}_{1}$ receptorinteracting proteins involved in the development of epileptiform seizures (Guggenhuber et al, 2015) and processes involving tolerance/resistance to the behavioral effects of cannabinoid drugs (Yao and Mackie, 2009). Moreover, different mechanisms have been shown to control selected signaling aspects of $\mathrm{CB}_{1}$ receptors that can clearly lead to behavioral consequences (Vallee et al, 2014; Busquets-Garcia et al, 2017; Pamplona et al, 2012)

New mechanisms aimed at protecting and endogenously modulate the activity of the ECS will be very likely described in the future. Each cell-type or subcellular localization of $\mathrm{CB}_{1}$ receptors might have a specific regulatory mechanism. The discovery of all these mechanisms, as in the case of pregnenolone (Vallee et al, 2014), will provide new tools to modulate the plethora of behavioral effects induced by cannabinoid drugs and, potentially, to develop new therapeutic tools against conditions characterized by excessive or reduced ECS activity.

\section{Postsynaptic Effects}

The exclusive presynaptic localization of neuronal $\mathrm{CB}_{1}$ receptors has been challenged based on new findings. Although the presynaptic localization and functions have been widely described (Castillo et al, 2012; Freund et al, 2003; Kano et al, 2009; Piomelli, 2003), there are studies demonstrating that cortical $\mathrm{CB}_{1}$ receptors can be also present and functional at the postsynaptic somatodendritic compartments of neurons where they can modulate self-inhibition processes (Bacci et al, 2004; Marinelli et al, 2009). Indeed, the first evidence suggesting the somatic presence of cannabinoid receptors came from the earlier 2000s when putative postsynaptic actions of cannabinoids in hippocampal neurons were shown (Schweitzer, 2000; Zhuang et al, 2005). Importantly, as we described in the second part of this review, recent work showed how the somatodendritic pool of $\mathrm{CB}_{1}$ receptors controls a specific postsynaptic signaling cascade, which is required for the cognitive impairment induced by cannabinoids (Maroso et al, 2016) (Figure 1).

These new results are especially important for the behavioral impact of $\mathrm{CB}_{1}$ receptor activation in specific cell types (Busquets-Garcia et al, 2015; Mackie, 2005). In this sense, the $\mathrm{CB}_{1}$ receptor functions in the postsynaptic compartment have been implicated in the cannabinoidinduced effects of spatial memory (Maroso et al, 2016). A quick search of the literature for 'memory deficits and cannabinoids', reveals a plethora of elegant studies demonstrating the possible involvement of $\mathrm{CB}_{1}$ receptors present in the presynaptic or postsynaptic compartment, in the plasma, or in mitochondrial membranes, or the involvement of different signaling pathways activated by these receptors (eg, MAPK-dependent pathways, mTOR pathway, and JNK) (Busquets-Garcia et al, 2015; Puighermanal et al, 2009; Vargish and McBain, 2016). Thus, future studies investigating the possible involvement of $\mathrm{mtCB}_{1}$ in the 'postsynaptic' effects of cannabinoids, the possible link between mTOR,
MAPK, or other signaling cascades and postsynaptic signaling pathways dependent of postsynaptic $\mathrm{CB}_{1}$ receptors, or the deep study on how different memory types engaged different $\mathrm{CB}_{1}$-dependent mechanisms will be necessary for the field.

\section{GENERAL CONCLUSION}

The ECS is amongst the most interesting and exciting discoveries of the last decades in the CNS. This discovery generated waves of 'lo and behold' about the new perspectives that it raised in the attempt to understand basic principles of brain functions. As it often and luckily happens in science, the ECS field has continuously evolved with new findings that push the concepts beyond the 'textbook' views. New data continue to challenge previous dogmas, providing refreshing revisions that boost interest in the large field touched by the ECS. The ambition of this short review was to simply highlight how new observations regarding $\mathrm{eCB}$ signaling in the brain still continue to open new perspectives on the complexity of brain function. With these premises, we believe that new surprises await us in the future, with new rigorous data opposing currently consolidated views. Given the pace and breadth of discoveries in the evolving eCB field, our hypothesis (and hope) is that this newly consolidated information will likely render this brief review obsolete in the next few years.

\section{FUNDING AND DISCLOSURE}

This work was supported by INSERM (to GM), EU-FP7 (PAINCAGE, HEALTH-603191 to GM and FP7PEOPLE-2013-IEF-623638 to AB-G), European Research Council (Endofood, ERC-2010-StG-260515, and CannaPreg, ERC-2014-PoC-640923, to GM), Fondation pour la Recherche Medicale (DRM20101220445 to GM), Human Frontiers Science Program (to GM), Region Aquitaine (to GM), French State/Agence Nationale de la Recherche (BRAIN ANR-10-LABX-0043 to GM, ANR-10-IDEX-03-02 to AB-G, NeuroNutriSens ANR-13-BSV4-0006-02 to GM, and ORUPS ANR-16-CE37-0010 to GM), Canadian Institutes for Health Research (CIHR, to JB), and Brain Canada (JB). The authors declare no conflict of interest.

\section{ACKNOWLEDGMENTS}

We thank Dr Georgina Balcells for her help in the figures design and drawings. We thank the Rebecca Hotchkiss International Scholar Exchange Program (RHISE) for supporting the collaborations between the HBI and Bordeaux Neuroscience.

\section{REFERENCES}

Accardi MV, Daniels BA, Brown PM, Fritschy JM, Tyagarajan SK, Bowie D (2014). Mitochondrial reactive oxygen species regulate the strength of inhibitory GABAmediated synaptic transmission. Nat Commun 5: 3168. 
Ahn KH, Mahmoud MM, Shim JY, Kendall DA (2013). Distinct roles of beta-arrestin 1 and beta-arrestin 2 in ORG27569-induced biased signaling and internalization of the cannabinoid receptor 1 (CB1). J Biol Chem 288: 9790-9800.

Aquila S, Guido C, Santoro A, Perrotta I, Laezza C, Bifulco M et al (2010). Human sperm anatomy: ultrastructural localization of the cannabinoid1 receptor and a potential role of anandamide in sperm survival and acrosome reaction. Anat Rec (Hoboken) 293: 298-309

Araque A, Carmignoto G, Haydon PG, Oliet SH, Robitaille R, Volterra A (2014). Gliotransmitters travel in time and space. Neuron 81: 728-739.

Araque A, Castillo PE, Manzoni OJ, Tonini R (2017). Synaptic functions of endocannabinoid signaling in health and disease. Neuropharmacology 124: 13-24.

Bacci A, Huguenard JR, Prince DA (2004). Long-lasting self-inhibition of neocortical interneurons mediated by endocannabinoids. Nature 431: 312-316.

Bagher AM, Laprairie RB, Kelly ME, Denovan-Wright EM (2013). Co-expression of the human cannabinoid receptor coding region splice variants $(\mathrm{hCB}(1))$ affects the function of hCB(1) receptor complexes. Eur J Pharmacol 721: 341-354.

Bagher AM, Laprairie RB, Kelly ME, Denovan-Wright EM (2016). Antagonism of dopamine receptor 2 long affects cannabinoid receptor 1 signaling in a cell culture model of striatal medium spiny projection neurons. Mol Pharmacol 89: 652-666.

Bartova A, Birmingham MK (1976). Effect of delta9-tetrahydrocannabinol on mitochondrial NADH-oxidase activity. J Biol Chem 251: 5002-5006.

Bauer M, Chicca A, Tamborrini M, Eisen D, Lerner R, Lutz B et al (2012). Identification and quantification of a new family of peptide endocannabinoids (Pepcans) showing negative allosteric modulation at CB1 receptors. J Biol Chem 287: 36944-36967.

Bellocchio L, Lafenetre P, Cannich A, Cota D, Puente N, Grandes P et al (2010). Bimodal control of stimulated food intake by the endocannabinoid system. Nat Neurosci 13: 281-283.

Benard G, Massa F, Puente N, Lourenco J, Bellocchio L, Soria-Gomez E et al (2012). Mitochondrial $\mathrm{CB}(1)$ receptors regulate neuronal energy metabolism. Nat Neurosci 15: 558-564.

Bino T, Chari-Bitron A, Shahar A (1972). Biochemical effects and morphological changes in rat liver mitochondria exposed to 1 -tetrahydrocannabinol. Biochim Biophys Acta 288: 195-202.

Blankman JL, Simon GM, Cravatt BF (2007). A comprehensive profile of brain enzymes that hydrolyze the endocannabinoid 2-arachidonoylglycerol. Chem Biol 14: 1347-1356.

Bloomfield MA, Ashok AH, Volkow ND, Howes OD (2016). The effects of Delta9tetrahydrocannabinol on the dopamine system. Nature 539: 369-377.

Blume LC, Patten T, Eldeeb K, Leone-Kabler S, Ilyasov AA, Keegan BM et al (2017). Cannabinoid receptor interacting protein 1a competition with beta-arrestin for CB1 receptor binding sites. Mol Pharmacol 91: 75-86.

Bosier B, Bellocchio L, Metna-Laurent M, Soria-Gomez E, Matias I, Hebert-Chatelain $\mathrm{E}$ et al (2013). Astroglial CB1 cannabinoid receptors regulate leptin signaling in mouse brain astrocytes. Mol Metab 2: 393-404.

Breivogel CS, Sim LJ, Childers SR (1997). Regional differences in cannabinoid receptor/G-protein coupling in rat brain. J Pharmacol Exp Ther 282: 1632-1642.

Brini M, Cali T, Ottolini D, Carafoli E (2014). Neuronal calcium signaling: function and dysfunction. Cell Mol Life Sci 71: 2787-2814.

Buck J, Sinclair ML, Schapal L, Cann MJ, Levin LR (1999). Cytosolic adenylyl cyclase defines a unique signaling molecule in mammals. Proc Natl Acad Sci USA 96: 79-84.

Busquets-Garcia A, Desprez T, Metna-Laurent M, Bellocchio L, Marsicano G, SoriaGomez E (2015). Dissecting the cannabinergic control of behavior: the where matters. BioEssays 37: 1215-1225.

Busquets-Garcia A, Gomis-Gonzalez M, Guegan T, Agustin-Pavon C, Pastor A, Mato $S$ et al (2013). Targeting the endocannabinoid system in the treatment of fragile X syndrome. Nat Med 19: 603-607.

Busquets-Garcia A, Gomis-Gonzalez M, Srivastava RK, Cutando L, Ortega-Alvaro A, Ruehle $S$ et al (2016). Peripheral and central CB1 cannabinoid receptors control stress-induced impairment of memory consolidation. Proc Natl Acad Sci USA 113: 9904-9909.

Busquets-Garcia A, Soria-Gomez E, Redon B, Mackenbach Y, Vallee M, Chaouloff F et al (2017). Pregnenolone blocks cannabinoid-induced acute psychotic-like states in mice. Mol Psychiatry. (e-pub ahead of print; doi:10.1038/mp.2017.4).

Caballero-Floran RN, Conde-Rojas I, Oviedo Chavez A, Cortes-Calleja H, Lopez-Santiago LF, Isom LL et al (2016). Cannabinoid-induced depression of synaptic transmission is switched to stimulation when dopaminergic tone is increased in the globus pallidus of the rodent. Neuropharmacology 110(Pt A): 407-418.

Callen L, Moreno E, Barroso-Chinea P, Moreno-Delgado D, Cortes A, Mallol J et al (2012). Cannabinoid receptors CB1 and CB2 form functional heteromers in brain. J Biol Chem 287: 20851-20865.
Campbell VA (2001). Tetrahydrocannabinol-induced apoptosis of cultured cortical neurones is associated with cytochrome c release and caspase- 3 activation. Neuropharmacology 40: 702-709.

Castillo PE, Younts TJ, Chavez AE, Hashimotodani Y (2012). Endocannabinoid signaling and synaptic function. Neuron 76: 70-81.

Chari-Bitron A, Bino T (1971). Effect of 1-tetrahydrocannabinol on ATPase activity of rat liver mitochondria. Biochem Pharmacol 20: 473-475.

Chávez AE, Chiu CQ, Castillo PE (2010). TRPV1 activation by endogenous anandamide triggers postsynaptic long-term depression in dentate gyrus. Nat Neurosci 13: 1511-1518.

Chen K, Neu A, Howard AL, Foldy C, Echegoyen J, Hilgenberg $L$ et al (2007). Prevention of plasticity of endocannabinoid signaling inhibits persistent limbic hyperexcitability caused by developmental seizures. J Neurosci 27: $46-58$.

Chen K, Ratzliff A, Hilgenberg L, Gulyas A, Freund TF, Smith M et al (2003). Longterm plasticity of endocannabinoid signaling induced by developmental febrile seizures. Neuron 39: 599-611.

Chen Y, Cann MJ, Litvin TN, lourgenko V, Sinclair ML, Levin LR et al (2000). Soluble adenylyl cyclase as an evolutionarily conserved bicarbonate sensor. Science $\mathbf{2 8 9}$ 625-628.

Cheng A, Hou Y, Mattson MP (2010). Mitochondria and neuroplasticity. ASN Neuro 2: $e 00045$.

Costa-Mattioli M, Monteggia LM (2013). mTOR complexes in neurodevelopmental and neuropsychiatric disorders. Nat Neurosci 16: 1537-1543.

Delgado-Peraza F, Ahn KH, Nogueras-Ortiz C, Mungrue IN, Mackie K, Kendall DA et al (2016). Mechanisms of biased beta-arrestin-mediated signaling downstream from the cannabinoid 1 receptor. Mol Pharmacol 89: 618-629.

Derkinderen P, Toutant M, Burgaya F, Le Bert M, Siciliano JC, de Franciscis V et al (1996). Regulation of a neuronal form of focal adhesion kinase by anandamide. Science 273: 1719-1722.

Derkinderen P, Valjent E, Toutant M, Corvol JC, Enslen H, Ledent C et al (2003). Regulation of extracellular signal-regulated kinase by cannabinoids in hippocampus. J Neurosci 23: 2371-2382.

Di Marzo V, De Petrocellis L, Fezza F, Ligresti A, Bisogno T (2002). Anandamide receptors. Prostaglandins Leukot Essent Fatty Acids 66: 377-391.

Diez-Alarcia R, Ibarra-Lecue I, Lopez-Cardona AP, Meana J, Gutierrez-Adan A, Callado LF et al (2016). Biased agonism of three different cannabinoid receptor agonists in mouse brain cortex. Front Pharmacol 7: 415.

Dubreucq S, Matias I, Cardinal P, Haring M, Lutz B, Marsicano G et al (2012). Genetic dissection of the role of cannabinoid type-1 receptors in the emotiona consequences of repeated social stress in mice. Neuropsychopharmacology 37: 1885-1900.

Fernandez-Ruiz J, Pazos MR, Garcia-Arencibia M, Sagredo O, Ramos JA (2008). Role of CB2 receptors in neuroprotective effects of cannabinoids. Mol Cell Endocrinol 286(1-2 Suppl 1): S91-S96.

Foldy C, Neu A, Jones MV, Soltesz I (2006). Presynaptic, activity-dependent modulation of cannabinoid type 1 receptor-mediated inhibition of GABA release. J Neurosci 26: 1465-1469.

Forss DA (1972). Odor and flavor compounds from lipids. Prog Chem Fats Other Lipids 13: 177-258.

Freund TF, Katona I, Piomelli D (2003). Role of endogenous cannabinoids in synaptic signaling. Physiol Rev 83: 1017-1066.

Gantz SC, Bean BP (2017). Cell-autonomous excitation of midbrain dopamine neurons by endocannabinoid-dependent lipid signaling. Neuron 93: 1375-1387 e1372.

Gentles AJ, Karlin S (1999). Why are human G-protein-coupled receptors predominantly intronless? Trends Genet 15: 47-49.

Glass M, Felder CC (1997). Concurrent stimulation of cannabinoid CB1 and dopamine D2 receptors augments CAMP accumulation in striatal neurons: evidence for a Gs linkage to the CB1 receptor. J Neurosci 17: 5327-5333.

Gomez-Gonzalo M, Navarrete M, Perea G, Covelo A, Martin-Fernandez M, Shigemoto $\mathrm{R}$ et al (2015). Endocannabinoids induce lateral long-term potentiation of transmitter release by stimulation of gliotransmission. Cereb Cortex 25: 3699-3712.

Guggenhuber S, Alpar A, Chen R, Schmitz N, Wickert M, Mattheus T et al (2016). Cannabinoid receptor-interacting protein Crip1a modulates CB1 receptor signaling in mouse hippocampus. Brain Struct Funct 221: 2061-2074.

Gulyas Al, Cravatt BF, Bracey MH, Dinh TP, Piomelli D, Boscia F et al (2004). Segregation of two endocannabinoid-hydrolyzing enzymes into pre- and postsynaptic compartments in the rat hippocampus, cerebellum and amygdala. Eur J Neurosci 20: 441-458.

Halassa MM, Haydon PG (2010). Integrated brain circuits: astrocytic networks modulate neuronal activity and behavior. Annu Rev Physiol 72: 335-355.

Han J, Kesner P, Metna-Laurent M, Duan T, Xu L, Georges F et al (2012). acute cannabinoids impair working memory through astroglial $\mathrm{CB}(1)$ receptor modulation of hippocampal LTD. Cell 148: 1039-1050. 
Hao S, Avraham Y, Mechoulam R, Berry EM (2000). Low dose anandamide affects food intake, cognitive function, neurotransmitter and corticosterone levels in dietrestricted mice. Eur J Pharmacol 392: 147-156.

Haring M, Enk V, Aparisi Rey A, Loch S, Ruiz de Azua I, Weber T et al (2015). Cannabinoid type-1 receptor signaling in central serotonergic neurons regulates anxiety-like behavior and sociability. Front Behav Neurosci 9: 235.

Harkany T, Horvath TL (2017). (S)Pot on mitochondria: cannabinoids disrupt cellular respiration to limit neuronal activity. Cell Metab 25: 8-10.

Hebert-Chatelain E, Desprez T, Serrat R, Bellocchio L, Soria-Gomez E, BusquetsGarcia A et al (2016). A cannabinoid link between mitochondria and memory. Nature 539: 555-559.

Hebert-Chatelain E, Reguero L, Puente N, Lutz B, Chaouloff F, Rossignol R et al (2014). Cannabinoid control of brain bioenergetics: exploring the subcellular localization of the CB1 receptor. Mol Metab 3: 495-504.

Heifets BD, Chevaleyre V, Castillo PE (2008). Interneuron activity controls endocannabinoid-mediated presynaptic plasticity through calcineurin. Proc Natl Acad Sci USA 105: 10250-10255.

Herkenham M, Lynn AB, Little MD, Johnson MR, Melvin LS, de Costa BR et al (1990). Cannabinoid receptor localization in brain. Proc Natl Acad Sci USA 87: 1932-1936.

Hermann H, Marsicano G, Lutz B (2002). Coexpression of the cannabinoid receptor type 1 with dopamine and serotonin receptors in distinct neuronal subpopulations of the adult mouse forebrain. Neuroscience 109: 451-460.

Hofer SC, Ralvenius WT, Gachet MS, Fritschy JM, Zeilhofer HU, Gertsch J (2015). Localization and production of peptide endocannabinoids in the rodent CNS and adrenal medulla. Neuropharmacology 98: 78-89.

Hojo M, Sudo Y, Ando Y, Minami K, Takada M, Matsubara T et al (2008). mu-Opioid receptor forms a functional heterodimer with cannabinoid CB1 receptor: electrophysiological and FRET assay analysis. J Pharmacol Sci 108: 308-319.

Howlett AC (1984). Inhibition of neuroblastoma adenylate cyclase by cannabinoid and nantradol compounds. Life Sci 35: 1803-1810.

Howlett AC (1987). Cannabinoid inhibition of adenylate cyclase: relative activity of constituents and metabolites of marihuana. Neuropharmacology 26: 507-512.

Howlett AC (2005). Cannabinoid receptor signaling. Handb Exp Pharmacol 168: 53-79.

Howlett AC, Barth F, Bonner TI, Cabral G, Casellas P, Devane WA et al (2002). International Union of Pharmacology. XXVII. Classification of cannabinoid receptors. Pharmacol Rev 54: 161-202.

Howlett AC, Breivogel CS, Childers SR, Deadwyler SA, Hampson RE, Porrino LJ (2004). Cannabinoid physiology and pharmacology: 30 years of progress. Neuropharmacology 47(Suppl 1): 345-358.

Hua T, Vemuri K, Pu M, Qu L, Han GW, Wu Y et al (2016). Crystal structure of the human cannabinoid receptor CB1. Cell 167: 750-762 e714.

Hua T, Vemuri K, Nikas SP, Laprairie RB, Wu Y, Qu L et al (2017). Crystal structures of agonist-bound human cannabinoid receptor $\mathrm{CB}(1)$. Nature 547: 468-471.

Hudson BD, Hebert TE, Kelly ME (2010). Ligand- and heterodimer-directed signaling of the $\mathrm{CB}(1)$ cannabinoid receptor. Mol Pharmacol 77: 1-9.

Hurst DP, Grossfield A, Lynch DL, Feller S, Romo TD, Gawrisch Ket al (2010). A lipid pathway for ligand binding is necessary for a cannabinoid $G$ protein-coupled receptor. J Biol Chem 285: 17954-17964.

Hurst DP, Schmeisser M, Reggio PH (2013). Endogenous lipid activated G proteincoupled receptors: emerging structural features from crystallography and molecular dynamics simulations. Chem Phys Lipids 169: 46-56.

Inda C, Dos Santos Claro PA, Bonfiglio JJ, Senin SA, Maccarrone G, Turck CW et al (2016). Different cAMP sources are critically involved in $G$ protein-coupled receptor CRHR1 signaling. J Cell Biol 214: 181-195.

Irannejad R, Pessino V, Mika D, Huang B, Wedegaertner PB, Conti M et al (2017). Functional selectivity of GPCR-directed drug action through location bias. Nat Chem Biol 13: 799-806.

Irannejad R, Tomshine JC, Tomshine JR, Chevalier M, Mahoney JP, Steyaert J et al (2013). Conformational biosensors reveal GPCR signalling from endosomes. Nature 495: 534-538.

Jalink K, Moolenaar WH (2010). G protein-coupled receptors: the inside story. Bioessays 32: 13-16.

Jong YJ, Sergin I, Purgert CA, O'Malley KL (2014). Location-dependent signaling of the group 1 metabotropic glutamate receptor mGlu5. Mol Pharmacol 86: 774-785.

Kano M, Ohno-Shosaku T, Hashimotodani Y, Uchigashima M, Watanabe M (2009). Endocannabinoid-mediated control of synaptic transmission. Physiol Rev 89: 309-380.

Katona I, Freund TF (2008). Endocannabinoid signaling as a synaptic circuit breaker in neurological disease. Nat Med 14: 923-930.

Katona I, Freund TF (2012). Multiple functions of endocannabinoid signaling in the brain. Annu Rev Neurosci 35: 529-558.
Katona I, Urban GM, Wallace M, Ledent C, Jung KM, Piomelli D et al (2006). Molecular composition of the endocannabinoid system at glutamatergic synapses. J Neurosci 26: 5628-5637.

Kearn CS, Blake-Palmer K, Daniel E, Mackie K, Glass M (2005). Concurrent stimulation of cannabinoid CB1 and dopamine D2 receptors enhances heterodimer formation: a mechanism for receptor cross-talk? Mol Pharmacol 67: 1697-1704.

Khajehali E, Malone DT, Glass M, Sexton PM, Christopoulos A, Leach K (2015). Biased agonism and biased allosteric modulation at the CB1 cannabinoid receptor. Mol Pharmacol 88: 368-379.

Khan SS, Lee FJ (2014). Delineation of domains within the cannabinoid CB1 and dopamine D2 receptors that mediate the formation of the heterodimer complex. J Mol Neurosci 53: 10-21.

Khan SM, Sung JY, Hébert TE (2016). G $\beta \gamma$ subunits-different spaces, different faces. Pharmacol Res 111: 434-441.

Kimura T, Cheng K, Rice KC, Gawrisch K (2009). Location, structure, and dynamics of the synthetic cannabinoid ligand CP-55,940 in lipid bilayers. Biophys J 96: 4916-4924.

Koch M, Varela L, Kim JG, Kim JD, Hernandez-Nuno F, Simonds SE et al (2015). Hypothalamic POMC neurons promote cannabinoid-induced feeding. Nature 519: 45-50.

Kreitzer AC, Carter AG, Regehr WG (2002). Inhibition of interneuron firing extends the spread of endocannabinoid signaling in the cerebellum. Neuron 34: 787-796.

Krohmer A, Brehm M, Auwärter V, Szabo B (2017). Pregnenolone does not interfere with the effects of cannabinoids on synaptic transmission in the cerebellum and the nucleus accumbens. Pharmacol Res 123: 51-61.

Kuzmiski JB, Pittman QJ, Bains JS (2009). Metaplasticity of hypothalamic synapses following in vivo challenge. Neuron 62: 839-849.

Lafenetre P, Chaouloff F, Marsicano G (2009). Bidirectional regulation of noveltyinduced behavioral inhibition by the endocannabinoid system. Neuropharmacology 57: 715-721.

Laplante M, Sabatini DM (2012). mTOR Signaling. Cold Spring Harbor Perspect Biol 4: 2.

Lee SH, Ledri M, Toth B, Marchionni I, Henstridge CM, Dudok B et al (2015). Multiple forms of endocannabinoid and endovanilloid signaling regulate the tonic control of GABA release. J Neurosci 35: 10039-10057.

Li Y, Kim J (2016). CB2 cannabinoid receptor knockout in mice impairs contextual long-term memory and enhances spatial working memory. Neural Plast 2016: 9817089.

Lourenco J, Cannich A, Carta M, Coussen F, Mulle C, Marsicano G (2010). Synaptic activation of kainate receptors gates presynaptic $\mathrm{CB}(1)$ signaling at GABAergic synapses. Nat Neurosci 13: 197-204.

Lu HC, Mackie K (2016). An introduction to the endogenous cannabinoid system. Biol Psychiatry 79: 516-525.

Mackie K, Hille B (1992). Cannabinoids inhibit N-type calcium channels in neuroblastoma-glioma cells. Proc Natl Acad Sci USA 89: 3825-3829.

Mackie K (2005). Distribution of cannabinoid receptors in the central and peripheral nervous system. Handb Exp Pharmacol 168: 299-325.

Mahoney JM, Harris RA (1972). Effect of 9-tetrahydrocannabinol on mitochondrial precesses. Biochem Pharmacol 21: 1217-1226.

Marinelli S, Pacioni S, Cannich A, Marsicano G, Bacci A (2009). Self-modulation of neocortical pyramidal neurons by endocannabinoids. Nat Neurosci 12: 1488-1490.

Maroso M, Szabo GG, Kim HK, Alexander A, Bui AD, Lee SH et al (2016). Cannabinoid control of learning and memory through $\mathrm{HCN}$ channels. Neuron 89 : 1059-1073.

Marsicano G, Goodenough S, Monory K, Hermann H, Eder M, Cannich A et al (2003). CB1 cannabinoid receptors and on-demand defense against excitotoxicity. Science 302: 84-88.

Marsicano G, Kuner R (2008). Anatomical distribution of receptors, ligands and enzymes in the brain and the spinal cord: circuitries and neurochemistry In: Kofalvi A (ed) Cannabinoids and the Brain. Springer: New York, NY, USA. pp 161-202.

Martin R, Bajo-Graneras R, Moratalla R, Perea G, Araque A (2015). GLIAL CELL SIGNALING. Circuit-specific signaling in astrocyte-neuron networks in basal ganglia pathways. Science 349: 730-734.

Mato S, Alberdi E, Ledent C, Watanabe M, Matute C (2009). CB1 cannabinoid receptor-dependent and -independent inhibition of depolarization-induced calcium influx in oligodendrocytes. Glia 57: 295-306.

Mattson MP, Gleichmann M, Cheng A (2008). Mitochondria in neuroplasticity and neurological disorders. Neuron 60: 748-766.

Mendizabal-Zubiaga J, Melser S, Benard G, Ramos A, Reguero L, Arrabal S et al (2016). Cannabinoid CB1 receptors are localized in striated muscle mitochondria and regulate mitochondrial respiration. Front Physiol 7: 476. 
Metna-Laurent M, Marsicano G (2015). Rising stars: modulation of brain functions by astroglial type-1 cannabinoid receptors. Glia 63: 353-364.

Metna-Laurent M, Soria-Gomez E, Verrier D, Conforzi M, Jego P, Lafenetre P et al (2012). Bimodal control of fear-coping strategies by CB(1) cannabinoid receptors. $\checkmark$ Neurosci 32: 7109-7118.

Miederer I, Uebbing K, Rohrich J, Maus S, Bausbacher N, Krauter K et al (2017). Effects of tetrahydrocannabinol on glucose uptake in the rat brain. Neuropharmacology 117: 273-281.

Mikasova L, Groc L, Choquet D, Manzoni OJ (2008). Altered surface trafficking of presynaptic cannabinoid type 1 receptor in and out synaptic terminals parallels receptor desensitization. Proc Natl Acad Sci USA 105: 18596-18601.

Min R, Nevian T (2012). Astrocyte signaling controls spike timing-dependent depression at neocortical synapses. Nat Neurosci 15: 746-753.

Miraucourt LS, Tsui J, Gobert D, Desjardins JF, Schohl A, Sild M et al (2016). Endocannabinoid signaling enhances visual responses through modulation of intracellular chloride levels in retinal ganglion cells. eLife 5: e15932.

Monory K, Massa F, Egertova M, Eder M, Blaudzun H, Westenbroek R et al (2006). The endocannabinoid system controls key epileptogenic circuits in the hippocampus. Neuron 51: 455-466.

Moreno E, Chiarlone A, Medrano M, Puigdellivol M, Bibic L, Howell LA et al (2017). Singular location and signaling profile of adenosine A2A-Cannabinoid CB1 receptor heteromers in the dorsal striatum. Neuropsychopharmacology (e-pub ahead of print; doi:10.1038/npp.2017.12).

Morré DJ, Mollenhauer HH (1974). The endomembrane concept: a functional integration of endoplasmic reticulum and Golgi apparatus. In: Robards AW (ed). Dynamic Aspects of Plant Infrastructure. McGraw-Hill: London, UK. pp 441-481.

Morozov YM, Ben-Ari Y, Freund TF (2004). The spatial and temporal pattern of fatty acid amide hydrolase expression in rat hippocampus during postnatal development. Eur J Neurosci 20: 459-466.

Navarrete M, Araque A (2008). Endocannabinoids mediate neuron-astrocyte communication. Neuron 57: 883-893.

Navarrete M, Araque A (2010). Endocannabinoids potentiate synaptic transmission through stimulation of astrocytes. Neuron 68: 113-126.

Navarro G, Morales P, Rodriguez-Cueto C, Fernandez-Ruiz J, Jagerovic N, Franco $R$ (2016). Targeting cannabinoid CB2 receptors in the central nervous system. Medicinal chemistry approaches with focus on neurodegenerative disorders. Front Neurosci 10: 406.

Niehaus JL, Liu Y, Wallis KT, Egertova M, Bhartur SG, Mukhopadhyay S et al (2007). CB1 cannabinoid receptor activity is modulated by the cannabinoid receptor interacting protein CRIP 1a. Mol Pharmacol 72: 1557-1566.

Nogueras-Ortiz C, Yudowski GA (2016). The multiple waves of cannabinoid 1 receptor signaling. Mol Pharmacol 90: 620-626.

Oddi S, Stepniewski TM, Totaro A, Selent J, Scipioni L, Dufrusine B et al (2017). Palmitoylation of cysteine 415 of $\mathrm{CB} 1$ receptor affects ligand-stimulated internalization and selective interaction with membrane cholesterol and caveolin 1. Biochim Biophys Acta 1862: 523-532.

Oliet SH, Baimoukhametova DV, Piet R, Bains JS (2007). Retrograde regulation of GABA transmission by the tonic release of oxytocin and endocannabinoids governs postsynaptic firing. J Neurosci 27: 1325-1333

Oliveira da Cruz JF, Robin LM, Drago F, Marsicano G, Metna-Laurent M (2016). Astroglial type-1 cannabinoid receptor (CB1): a new player in the tripartite synapse. Neuroscience 323: 35-42.

Omiya Y, Uchigashima M, Konno K, Yamasaki M, Miyazaki T, Yoshida T et al (2015). VGluT3-expressing CCK-positive basket cells construct invaginating synapses enriched with endocannabinoid signaling proteins in particular cortical and cortexlike amygdaloid regions of mouse brains. J Neurosci 35: 4215-4228.

Onaivi ES, Chaudhuri G, Abaci AS, Parker M, Manier DH, Martin PR et al (1999). Expression of cannabinoid receptors and their gene transcripts in human blood cells. Prog Neuropsychopharmacol Biol Psychiatry 23: 1063-1077.

Onaivi ES, Ishiguro H, Gu S, Liu QR (2012). CNS effects of CB2 cannabinoid receptors: beyond neuro-immuno-cannabinoid activity. J Psychopharmacol 26: 92-103.

Ortega-Alvaro A, Aracil-Fernandez A, Garcia-Gutierrez MS, Navarrete F, Manzanares $J$ (2011). Deletion of CB2 cannabinoid receptor induces schizophrenia-related behaviors in mice. Neuropsychopharmacology 36: 1489-1504.

Oz M, Ravindran A, Diaz-Ruiz O, Zhang L, Morales M (2003). The endogenous cannabinoid anandamide inhibits alpha7 nicotinic acetylcholine receptormediated responses in Xenopus oocytes. J Pharmacol Exp Ther 306: 1003-1010.

Pamplona FA, Ferreira J, Menezes de Lima O Jr, Duarte FS, Bento AF, Forner S et al (2012). Anti-inflammatory lipoxin A4 is an endogenous allosteric enhancer of CB1 cannabinoid receptor. Proc Natl Acad Sci USA 109: 21134-21139.

Pelkey KA, Lavezzari G, Racca C, Roche KW, McBain CJ (2005). mGluR7 is a metaplastic switch controlling bidirectional plasticity of feedforward inhibition. Neuron 46: 89-102.
Perrey DA, Gilmour BP, Thomas BF, Zhang Y (2014). Toward the development of bivalent ligand probes of cannabinoid $\mathrm{CB} 1$ and Orexin OX1 receptor heterodimers. ACS Med Chem Lett 5: 634-638.

Piazza PV, Cota D, Marsicano G (2017). The CB1 receptor as the cornerstone of exostasis. Neuron 93: 1252-1274.

Piazza PV, Vallee M, Marsicano G, Felpin FX, Bellocchio L, Cota D et al (2012). Antagonists of CB1 receptor. In: WIPO (ed). Available at https://www.google.fr/ patents/US20140200200?dq=piazza+marsicano\&hl=en\&sa=X\&ved=0ahUKEwi d4oGi7s_WAhVCbVAKHWodB1cQ6AEIPjAC. Accessed 1 October 2017.

Picard M (2015). Mitochondrial synapses: intracellular communication and signal integration. Trends Neurosci 38: 468-474.

Piomelli D (2003). The molecular logic of endocannabinoid signalling. Nat Rev Neurosci 4: 873-884.

Prather PL, Martin NA, Breivogel CS, Childers SR (2000). Activation of cannabinoid receptors in rat brain by WIN 55212-2 produces coupling to multiple G protein alpha-subunits with different potencies. Mol Pharmacol 57: 1000-1010.

Puente N, Cui Y, Lassalle O, Lafourcade M, Georges F, Venance L et al (2011). Polymodal activation of the endocannabinoid system in the extended amygdala. Nat Neurosci 14: 1542-1547.

Puighermanal E, Marsicano G, Busquets-Garcia A, Lutz B, Maldonado R, Ozaita A (2009). Cannabinoid modulation of hippocampal long-term memory is mediated by mTOR signaling. Nat Neurosci 12: 1152-1158.

Raefsky SM, Mattson MP (2017). Adaptive responses of neuronal mitochondria to bioenergetic challenges: roles in neuroplasticity and disease resistance. Free Radic Biol Med 102: 203-216.

Raehal KM, Bohn LM (2014). Beta-arrestins: regulatory role and therapeutic potential in opioid and cannabinoid receptor-mediated analgesia. Handb Exp Pharmacol 219: 427-443.

Rangaraju V, Calloway N, Ryan TA (2014). Activity-driven local ATP synthesis is required for synaptic function. Cell 156: 825-835.

Reggio PH (2010). Endocannabinoid binding to the cannabinoid receptors: what is known and what remains unknown. Curr Med Chem 17: 1468-1486.

Rey AA, Purrio M, Viveros MP, Lutz B (2012). Biphasic effects of cannabinoids in anxiety responses: $\mathrm{CB} 1$ and $\mathrm{GABA}(\mathrm{B})$ receptors in the balance of GABAergic and glutamatergic neurotransmission. Neuropsychopharmacology 37: 2624-2634.

Rozenfeld R, Devi LA (2008). Regulation of CB1 cannabinoid receptor trafficking by the adaptor protein AP-3. FASEB J 22: 2311-2322.

Ruehle S, Wager-Miller J, Straiker A, Farnsworth J, Murphy MN, Loch S et al (2017). Discovery and characterization of two novel CB1 receptor splice variants with modified N-termini in mouse. J Neurochem 142: 521-533.

Schurr A, Livne A (1975). Proceedings: Differential inhibition of mitochondria monoamine oxidase from brain by hashish components. Israel J Med Sci 11: 1188

Schweitzer P (2000). Cannabinoids decrease the $K(+)$ M-current in hippocampal CA1 neurons. J Neurosci 20: 51-58.

Shao Z, Yin J, Chapman K, Grzemska M, Clark L, Wang J et al (2016). Highresolution crystal structure of the human CB1 cannabinoid receptor. Nature (e-pub ahead of print; doi:10.1038/nature20613)

Sigel E, Baur R, Racz I, Marazzi J, Smart TG, Zimmer A et al (2011). The major central endocannabinoid directly acts at $\mathrm{GABA}(\mathrm{A})$ receptors. Proc Natl Acad Sci USA 108: 18150-18155.

Smith TH, Blume LC, Straiker A, Cox JO, David BG, McVoy JR et al (2015). Cannabinoid receptor-interacting protein 1a modulates CB1 receptor signaling and regulation. Mol Pharmacol 87: 747-765.

Smith TH, Sim-Selley LJ, Selley DE (2010). Cannabinoid CB1 receptor-interacting proteins: novel targets for central nervous system drug discovery? Br J Pharmacol 160: 454-466.

Soria-Gomez E, Busquets-Garcia A, Hu F, Mehidi A, Cannich A, Roux L et al (2015). Habenular CB1 receptors control the expression of aversive memories. Neuron 88: 306-313.

Steegborn C (2014). Structure, mechanism, and regulation of soluble adenylyl cyclases - similarities and differences to transmembrane adenylyl cyclases. Biochim Biophys Acta 1842(12 Pt B): 2535-2547.

Steindel F, Lerner R, Haring M, Ruehle S, Marsicano G, Lutz B et al (2013). Neurontype specific cannabinoid-mediated $\mathrm{G}$ protein signalling in mouse hippocampus. J Neurochem 124: 795-807.

Straiker A, Wager-Miller J, Hutchens J, Mackie K (2012). Differential signalling in human cannabinoid CB1 receptors and their splice variants in autaptic hippocampal neurones. Br J Pharmacol 165: 2660-2671.

Sultan S, Li L, Moss J, Petrelli F, Casse F, Gebara E et al (2015). Synaptic integration of adult-born hippocampal neurons is locally controlled by astrocytes. Neuron $\mathbf{8 8}$ 957-972.

Suzuki A, Stern SA, Bozdagi O, Huntley GW, Walker RH, Magistretti PJ et al (2011). Astrocyte-neuron lactate transport is required for long-term memory formation. Cell 144: 810-823.

Turu G, Hunyady L (2010). Signal transduction of the CB1 cannabinoid receptor. J1 Mol Endocrinol 44: 75-85. 
Thibault K, Carrel D, Bonnard D, Gallatz K, Simon A, Biard M et al (2013). Activationdependent subcellular distribution patterns of CB1 cannabinoid receptors in the rat forebrain. Cereb Cortex 23: 2581-2591.

Tsvetanova NG, Irannejad R, von Zastrow M (2015). G protein-coupled receptor (GPCR) signaling via heterotrimeric G proteins from endosomes. J Biol Chem 290: 6689-6696.

Twitchell W, Brown S, Mackie K (1997). Cannabinoids inhibit N- and P/Q-type calcium channels in cultured rat hippocampal neurons. J Neurophysio/ 78: 43-50.

Vallee M, Vitiello S, Bellocchio L, Hebert-Chatelain E, Monlezun S, Martin-Garcia E et al (2014). Pregnenolone can protect the brain from cannabis intoxication. Science 343: 94-98.

Vargish GA, McBain CJ (2016). The hyperpolarization-activated cation current Ih: the missing link connecting cannabinoids to cognition. Neuron 89: 889-891.

Vasquez C, Lewis DL (1999). The CB1 cannabinoid receptor can sequester G-proteins, making them unavailable to couple to other receptors. J Neurosci 19: 9271-9280.

Vinals X, Moreno E, Lanfumey L, Cordomi A, Pastor A, de La Torre R et al (2015). Cognitive impairment induced by delta9-tetrahydrocannabinol occurs through heteromers between cannabinoid CB1 and serotonin 5-HT2A receptors. PLOS Biol 13: e1002194.

Voelker DR (1991). Organelle biogenesis and intracellular lipid transport in eukaryotes. Microbiol Rev 55: 543-560.

Wager-Miller J, Westenbroek R, Mackie K (2002). Dimerization of G protein-coupled receptors: CB1 cannabinoid receptors as an example. Chem Phys Lipids 121: 83-89.

Wamsteeker Cusulin JI, Senst L, Teskey GC, Bains JS (2014). Experience salience gates endocannabinoid signaling at hypothalamic synapses. J Neurosci 34: 6177-6181.

Wamsteeker JI, Bains JS (2010a). A synaptocentric view of the neuroendocrine response to stress. Eur J Neurosci 32: 2011-2021.

Wamsteeker JI, Kuzmiski JB, Bains JS (2010b). Repeated stress impairs endocannabinoid signaling in the paraventricular nucleus of the hypothalamus. J Neurosci 30: 11188-11196.

Wittmann G, Deli L, Kallo I, Hrabovszky E, Watanabe M, Liposits Z et al (2007). Distribution of type 1 cannabinoid receptor (CB1)-immunoreactive axons in the mouse hypothalamus. J Comp Neurol 503: 270-279.

www.nobelprize.org (2014). The Nobel Prize in Chemistry 2012-Advanced Information. https://www.nobelprize.org/nobel_prizes/chemistry/laureates/2012/.

Xiong W, Wu X, Li F, Cheng K, Rice KC, Lovinger DM et al (2012). A common molecular basis for exogenous and endogenous cannabinoid potentiation of glycine receptors. J Neurosci 32: 5200-5208.
Yao B, Mackie K (2009). Endocannabinoid receptor pharmacology. Curr Top Behav Neurosci 1: 37-63.

Yoshida T, Uchigashima M, Yamasaki M, Katona I, Yamazaki M, Sakimura K et al (2011). Unique inhibitory synapse with particularly rich endocannabinoid signaling machinery on pyramidal neurons in basal amygdaloid nucleus. Proc Natl Acad Sci USA 108: 3059-3064.

Younts TJ, Chevaleyre V, Castillo PE (2013). CA1 pyramidal cell theta-burst firing triggers endocannabinoid-mediated long-term depression at both somatic and dendritic inhibitory synapses. J Neurosci 33: 13743-13757.

Younts TJ, Monday HR, Dudok B, Klein ME, Jordan BA, Katona I et al (2016). Presynaptic protein synthesis is required for long-term plasticity of GABA release. Neuron 92: 479-492.

Zhu PJ, Lovinger DM (2007). Persistent synaptic activity produces long-lasting enhancement of endocannabinoid modulation and alters long-term synaptic plasticity. J Neurophysiol 97: 4386-4389.

Zhuang S, Hampson RE, Deadwyler SA (2005). Behaviorally relevant endocannabinoid action in hippocampus: dependence on temporal summation of multiple inputs. Behav Pharmacol 16: 463-471.

Zygmunt PM, Petersson J, Andersson DA, Chuang H, Sørgård M, Di Marzo V et al (1999). Vanilloid receptors on sensory nerves mediate the vasodilator action of anandamide. Nature 400: 452-457.

This work is licensed under a Creative Commons Attribution-NonCommercial-ShareAlike

4.0 International License. The images or other third party material in this article are included in the article's Creative Commons license, unless indicated otherwise in the credit line; if the material is not included under the Creative Commons license, users will need to obtain permission from the license holder to reproduce the material. To view a copy of this license, visit http://creativecommons.org/licenses/by-nc-sa/4.0/

(C) The Author(s) 2018 